\title{
RECENT AMENDMENTS TO THE KOREAN COMMERCIAL CODE AND THEIR EFFECTS ON INTERNATIONAL COMPETITION
}

\author{
JOONGI KIM*
}

\section{INTRODUCTION: SEARCHING FOR THE ORIGINS OF THE CRISIS}

Corporate law in Korea has undergone a dramatic transformation in recent years. In an effort to revamp Korean corporations, the Korean government made sweeping reforms to Korea's Commercial Code (sang-bup) three times in the past four yearsin 1995, 1998, and 1999. These newly amended provisions have

* Assistant Professor of Law, Graduate School of International Studies (GSIS), Yonsei University, Seoul, Korea; B.A., Columbia College; M.A., GSIS, Yonsei University; J.D., Georgetown University Law Center. This paper was supported by a grant from the Non-Directed Research Fund of the Korea Research Foundation. The author would like to thank David S. Cho, Dong Woo Suh, Inbeom Chung, Mina Kim, Jay Shin, Deborah Ranger, Byung-soo Kim, Jae Young Kim, and Jihong Joo for their guidance and assistance in preparing this article.

1 See Commercial Code, Law No. 1000 of 1962 (as amended Law No. 5053 of 1995, Law No. 5591 of 1998 and Law No. 6086 of 2000) ("KCC"). The corporate law section of Korea's Commercial Code can be found between Articles 169 and 637. In this Article, the changes will be referred to as "1995 KCC," "1998 KCC," and "1999 KCC" respectively, and simply "KCC" if no changes were made in 1995, 1998, or 1999. For a critical view on how the KCC and the Securities Exchange Act ("SEA") should be amended to harmonize each other, see $\mathrm{Ki}$-won Choi, IMF ui geuk-bok-eul wui-ban sang-bup-gae-jung bang-byang (I)

[How the Korean Commercial Code Should Be Amended to Overcome the IMF Situation (I), L. TIMES (Seoul), Apr. 13, 1998, at 14.

Other major laws that can apply to corporations include the Civil Code, the SEA, the Securities Investment Trust Business Act, the Securities Investment Company Act, the Foreign Exchange Trade Act, the Bankruptcy Act, and the Composition Act. See Securities Investment Company Act, Law No. 5557 of 1998 (as amended Law No. 6174 of 2000); Foreign Exchange Trade Act, Law No. 4447 of 1991 (as amended Law No. 5550 of 1998); Securities Investment Trust Business Act, Law No. 2129 of 1969 (as amended Law No. 6179 of 2000); Bankruptcy Act, Law No. 998 of 1962 (as amended Law No. 61115519 of 2000); Composition Act, Law No. 997 of 1962 (as amended Law No. 6110 of 2000); SEA, Law No. 972 of 1962 (as amended Law No. 6176 of 2000); and Civil Code, Law No. 471 of 1958 (as amended Law No. 5454 of 1997). 
set in motion unprecedented changes for the Korean corporate environment. Korean management is finally beginning to be monitored and challenged in a more meaningful manner, while at the same time, directors and auditors have gained both renewed authority and responsibilities. Shareholder rights have been strengthened to levels previously unimaginable by Korean standards. ${ }^{2}$ The number of mergers and acquisitions has risen noticeably, and unfriendly corporate takeovers have even been attempted. ${ }^{3}$ Although still far from international standards, these new corporate regulations not only can assist other industrializing countries that are contemplating similar regulatory changes, but they can also contribute to the debate surrounding the potential for global convergence in corporate governance. ${ }^{4}$

More specifically, the 1995 amendments ("1995 KCC") marked only the second time that Korea amended its corporate law section of the KCC since the KCC's initial enactment in 1962..$^{5}$ The 1995 amendments attempted to address a broad range

2 See infra Section 3.3.

3 See KOREA FAIR TRADE COMM'N, TONG-gYE-YON-BO [ANNUAL STATISTICS], Mar. 26, 1999 (visited Apr. 10, 2000) <http://www.ftc.go.kr>. See infra Section 4.2 for examples of recent unfriendly takeover attempts. The number of mergers filed with the Korea Fair Trade Commission that involved companies with total assets or sales greater than 100 billion won (U.S. $\$ 83$ million) were as follows:

\begin{tabular}{|l|l|l|l|l|l|l|l|l|}
\hline & 1992 & 1993 & 1994 & 1995 & 1996 & 1997 & 1998 & 1999 \\
\hline $\begin{array}{l}\text { Merger } \\
\text { Filings }\end{array}$ & 62 & 55 & 48 & 48 & 63 & 75 & 151 & 145 \\
\hline
\end{tabular}

4 Malaysia, Indonesia, and Thailand are some other countries that are pursuing reform in their corporate governance regulations. See ANDREW STONE ET AL., THE BUSINESS ENVIRONMENT AND CORPORATE GOVERNANCE: STRENGTHENING INCENTIVES FOR PRTVATE SECTOR PERFORMANCE, 6.7 (1998) (visited Apr. 16, 2000) <http://www.worldbank.org/html/fpd/ privatesector $/ \mathrm{cg} /$ docs/busenvp8.pdf $>$ (one of five papers prepared by World Bank staff for their 1998 annual meeting); $c f$. John C. Coffee, Jr., The Future as History: The Prospects for Global Convergence in Corporate Governance and Its Implications, 93 Nw. U. L. REV. 641 (1999); Roberta Romano, A Cautionary Note on Drawing Lessons from Comparative Corporate Law, 102 YALE L.J. 2021 (1993).

5 But see Ki-won Choi, Sang-bup-gae-jung-an-ui moon-jae-jum [The Problems with the Proposal to Amend the Commercial Code], L. TIMES (Seoul), June 13, 1994, at 14 (suggesting that the Commercial Code was being revised too frequently). The last time the corporate law section of the KCC was substantively amended occurred in 1984. See Law No. 3724 of 1984. See generally Gil- 
of issues including shareholder rights, the regulation of mergers and acquisitions, and the role of directors and auditors. Many of these changes had been long advocated, but were often delayed under the pretext that corporations were not ready. ${ }^{6}$ Before the impact of the $1995 \mathrm{KCC}$ could fully be measured, however, Korea's economy plunged into one of the worst recessions in its history, falling victim to the financial contagion that swept across most of Asia in 1997?

The 1997 financial crisis exposed a wide range of structural weaknesses in Korea's economy. International organizations such as the International Monetary Fund ("IMF") and the International Bank for Reconstruction and Development ("World Bank"), in particular, criticized Korea's corporate sector and blamed ineffective corporate regulation as a major cause of the crisis. ${ }^{8}$ In addition to corporate sector reforms, such as corporate

jun Park, Gae-jung-sang-bup-bae-sul [Explanation of the Amended Commercial Code], Jeung-gwon, Mar. 1984, at 37 (providing background on the 1984 amendments to the $\mathrm{KCC}$ ).

6 See Hee-chul Chung, Sang-bup-gae-jung-si-an-ui moon-jae-jum [Problems with the Proposed Amendments to the Commercial Code], 23 BUP-HAK [hereinafter SEOU L.J.] 1 (1982) [hereinafter Hee-chul Chung, Problems]; Hee-chul Chung, Sang-bup-gae-jung-an-ui gae-yo-wa moon-jae-jum [Summary of, and Problems with, the Proposed Amendments to the Commercial Code] 24 SEOUL L.J. 24 (1982) [hereinafter Hee-chul Chung, Summary]; Ju-chan Sonn, Han-gook-sangbup-gae-jung-ui bwoe-go [Reflections on Amendments to Korea's Commercial Code], 10 SANG-SA-BUP-YON-Goo [hereinafter COM. L. REV.] 25 (1992) [hereinafter Ju-chan Sonn, Reflections]; Ju-chan Sonn, Sang-bup-gae-jung-an-ui moonjae-jum' ui moon-jae-jum [The Problems with 'The Problems with the Proposed Amendments to the Commercial Code', L. TIMES (Seoul), June 23, 1994, at 15.

7 See generally TOMÁs J.T. BALINO \& ANGEL UBDE, THE KOREAN FINANCIAL CRISIS OF 1997-A STRATEGY OF FINANCIAL SECTOR REFORM (International Monetary Fund Working Paper No. WP/99/28, 1999) (providing a comprehensive view on the origins of the crisis and how it affected Korea); Nouriel Roubini, What Caused Asia's Economic and Currency Crisis and Its Global Contagion? (visited Apr. 10, 2000) < http://www.stern.nyu.edu $/ \sim$ nroubini/asia/AsiaHomepage.html $>$ (displaying links and articles on causes of Asian financial crisis).

${ }^{8}$ See BALIÑO \& UBIDE, supra note 7, at 7 (" $[\mathrm{L}]$ ack of transparency in financial and corporate sectors, weak governance, and poor regulatory systems hampered the efficient functioning of markets in disciplining the Korean economy."). In its "Letter of Development Policy" concerning the Second Structural Adjustment Loan from the World Bank, the Korean government admitted that " $[\tau] 0$ restore, and sustain, financial viability and competitiveness, Korean firms need both financial and real restructuring. The latter requires improvements in the governance of firms and increased exposure to competitive pressures." Letter from Kyu-Sung Lee, Minister of Finance and Economy, to James D. Wolfensohn, President, International Bank for Reconstruction and 
financial restructuring and corporate governance, the World Bank and IMF also cited structural problems related to macroeconomic reforms, financial sector reforms, and labor reforms. ${ }^{9}$ In return for receiving their financial assistance, Korea enacted another round of extensive amendments to its corporate laws on December 28, 1998 ("1998 KCC"). ${ }^{10}$ While the $1998 \mathrm{KCC}$ arose out of unfortunate circumstances, the financial crisis provided the impetus to further overhaul the KCC and implement reforms that remained unfinished after the 1995 amendments. Finally, on December 31, 1999, several additional amendments were enacted ("1999 KCC"). Although not as extensive, the $1999 \mathrm{KCC}$ in particular included new provisions governing stock options and audit committees.

This background provides an appropriate juncture at which to assess the impact and potential of the 1995, 1998, and 1999 amendments to the KCC. This Article will begin with a discussion of the major problems that previously existed in corporate regulation. It will seek to show that these shortcomings not only left Korean corporations uncompetitive, but also vulnerable to external shocks. Next, the Article will review, in depth, the major amendments that were recently made to the KCC. ${ }^{11}$ The up-

Development, para. 7 (Sept. 24, 1998), <http://www.worldbank.org/html/ extdr/offrep/eap/krsalii/ldp.html > [hereinafter Letter from Kyu-Sung Lee].

9 See BALIÑO \& UBIDE, supra note 7; Letter from Kyu-Sung Lee, supra note 8.

${ }^{10}$ See Letter from Kyu-Sung Lee, supra note 8; Letter from Kyung-Shik Lee, Governor, Bank of Korea, and Chang-Yeul Lim, Deputy Prime Minister and Minister of Finance and Economy, to Michel Camdessus, Managing Director, International Monetary Fund (Feb. 7, 1998) (visited Feb. 21, 2000) <http://www.imf.org/external/np/loi/020798.htm>; World Bank, Korea Second Structural Adjustment Loan Corporate Sector Reform Matrix, Part B: Corporate Governance, Competition Policies, and Reform and Privatization of StateOwned Enterprises (visited Mar. 6, 2000) <http://www.worldbank.org/html/ extdr/offrep/eap/krsalii/matcorps.html>; see also Steven Mufson, Rebuilding South Korea's House of Cards; Conglomerates Totter Under Costs, Corruption, WASH. POST, Dec. 22, 1997, at A1; Alan Murray, Asia's Turmoil Accents Wall Street's Strengths, ASIAN WALL ST. J., Dec. 9, 1997, at 6.

${ }_{11}$ The KCC provides for four types of companies: hap-ja-bwoe-sa (limited partnerships), bap-myung-bwoe-sa (general partnerships), yoo-ban-bwoe-sa (limited liability companies), and joo-shik-bwoe-sa (stock corporations). See KCC art. 170. This Article will focus on the changes to stock corporations, which account for more than $92 \%$ of all companies in Korea. See CHUL-SONG LEE, SANG-BUP-GANG-UI [LECTURES ON THE COMMERCIAL CODE] 251 (1997). See $\mathrm{KCC}$ articles 288 to 542 for the provisions in the KCC that primarily govern stock corporations. 
shot of these new laws will then be examined through several recent case studies. Lastly, some of the major unresolved issues will be explored.

Overall, this Article will conclude that the recent changes to the KCC are reshaping the Korean corporate environment in an unprecedented fashion. For the first time, firms must establish more effective checks and balances, and become more transparent and accountable. While some reforms still languish, these changes have set into motion a reorientation of the governance structure of Korean corporations. The recent measures, as a whole, will help enhance the competitiveness of corporate Korea and allow it to become a more serious contender in the international marketplace.

\section{THE SHORTCOMINGS OF CORPORATE KOREA}

Not many countries can claim the type of post-war economic success that Korea has achieved. By the end of 1996, Korea became the eleventh largest economy, with a per capita income of over U.S. $\$ 10,000$ in the span of three decades. When the 1997 financial crisis hit, however, the economy and corporate Korea alike collapsed, unable to withstand the shocks of the crisis. Korean corporations, therefore, stand at a critical crossroad because they must find a way to resolve the inherent weaknesses that were exposed during the crisis.

Most of the faults in Korean corporations can be traced to the failure of the corporate regulatory framework. In essence, the management structure established to oversee business firms did not function as expected. ${ }^{12}$ Corporate actors, such as shareholders, the board of directors, representative directors, and auditors,

12 In addition to internal corporate governance, Korean companies also suffered from weak external governance. An active mergers and acquisitions market did not exist, bankruptcies were difficult to pursue, external accounting oversight was rare, and banks failed to properly control lending practices. See Seung-min Yoo, Dae-gi-up gyung-young-goo-jo-ui moon-jae-jum-gwa gae-sun-bangan [Problems of, and a Proposal to Improve, the Management Structure of Large Corporations], 36 SANG-JANG-HYUP 11, 18 (1997) (discussing the lack of monitoring by creditors). See generally Michael Schuman, Piling On: For Korea's Banks, Hanbo Is Merely the Latest Shock, ASIAN WALL ST. J., Feb. 3, 1997, at 1 [hereinafter Schuman, Piling On]; South Korean Bankruptcy: Death, Where Is Thy Sting?, ECONOMIST, July 17, 1999, at 61 (discussing South Korea's weak bankruptcy laws). 
did not fulfill their respective statutory duties. ${ }^{13}$ One expert describes the anomalous situation whereby Korean boards would monitor themselves as being functionally in between the dualboard system or two-tier system of Germany, and the singleboard or one-tier system of the United States. ${ }^{14}$ Shareholders, whether they were individual or institutional investors, did not monitor corporate affairs. Directors and auditors, in turn, had little incentive to act as responsible fiduciaries on behalf of the interests of all shareholders.

Over time, an ineffective system of corporate governance emerged that was saddled with opaque business practices and an overall lack of checks and balances. ${ }^{15}$ Under this lax management structure, principal shareholders have dominated the affairs of the corporation, serving as both chief owner and manager. Eventually, this unchallenged rule by corporate chieftains created enormous agency costs and left Korean corporations structurally vulnerable and uncompetitive.

${ }^{13}$ The board of directors system was adopted from the Japanese system, which, in turn, was based on the U.S. system. See Dong-yoon Chung, Sang-bup sa-ship-ob-nyun: ge bwoe-go wa jun-mang [45 Years of the Korean Commercial Code: Its Past and Future], in HAN-GOOK BUP-HAK UI HWOE-GO WA JUNMANG [THE PAST AND FUTURE OF KOREAN LAW] 343, 356 (1991); see also Thomas L. Blakemore \& Makoto Yazawa, Japanese Commercial Code Revisions: Concerning Corporations, 2 AM. J. COMP. L. 12, 12, 15-16 (1953) (" On a Commercial Code of continental origin, there have been forcibly grafted certain limbs of alien, Anglo-American origin."); Lester N. Salwin, The New Commercial Code of Japan: Symbol of Gradual Progress Toward Democratic Goals, 50 GEO. L.J. 478, 504 (1962) (detailing the duties of board officers under the new commercial code).

${ }^{14}$ See Chan-hyung Chung, Gi-up-gyung-young-ui too-myung-sung-jae-go-reul wui-ban joo-Shik-bwoe-sa-ui ji-bae-goo-jo-ui gae-sun (II) [Improving Corporate Governance of Stock Corporations to Enhance Transparency of Corporate Management (II)], L. TMMES (Seoul), May 7, 1998, at 14.

${ }_{15}$ See Dae-hong Chang, Joo-joo-joong-shi gyong-young-gwa gi-up-ji-bae-goo-jo gae-sun [Management that Places Importance on Sharebolders and Improving Corporate Governance], 39 SANG-JANG-HYUP 36 (1999); Soo-geun Oh, Bi-ji-bae-joo. joo-ui gwon-li-bo-bo-wa gyung-yong-too-myung-sung-ui jae-go [Protecting the Rights of Nonprincipal Sharebolders and Enbancing Managerial Transparency], 37 SANGJANG-HYUP 69, 73-81 (1998). 


\subsection{Dominant Principal Shareholders and Ineffective Boards of Directors, Representative Directors, and Auditors}

For most publicly held companies in Korea, principal shareholders unilaterally dictated corporate policy. ${ }^{16}$ These principal shareholders dominated corporate affairs without any checks or balances in place regarding their decisions, unaccountable to anyone but themselves. ${ }^{17}$ In essence, they naturally placed their interests above the interests of the other shareholders because no pressure existed to act otherwise, creating an enormous agency problem.

Principal shareholders commanded all facets of corporate affairs, including board decisions, the selection of directors or auditors, and shareholders' meetings. ${ }^{18}$ Principal shareholders singlehandedly appointed directors and auditors. Candidates were selected from company employees, with one of the most important

${ }^{16}$ See Jong-ho Na \& Young-shin Yoon, Chae-bol gae-hyuk (2) [Reform of the Chaebol (2)], CHOSUN ILBO (Seoul), Jan. 3, 1998, at 11. A classic example occurred in 1994 when the Chairman of the Dong Ah group unilaterally announced, without considering shareholder interests, that his construction company accepted moral responsibility for a collapsed bridge and would donate 150 billion won (U.S. $\$ 125$ million) to the city of Seoul to rebuild it. See Hyo-sang Kang, Dae-gi-up ob-nub' dok-joo' man-ta [Many Owners of Large Conglomerates Act "Unilaterally"], CHOSUN ILBO, May 10, 1996, at 11; Young-am Park \& Ik-won Lee, So-soo-joo-joo 'nae-mok-da-ob' [Minority Stockholders, "Give Us Our Share'], BUSINESS (Seoul), Apr. 29, 1997, at 66.

${ }_{17}$ See Keo-san Lee \& Young-shin Yoon, Chae-bol gae-hyuk (7) [Reform of the Chaebol ( ))], CHOSUN IIBO, Jan. 8, 1998, at 9; Ui-joon Park, Gi-up mung-deulgae-ba-myun ge-man-keum go-tong-joon-da [Those that Harm Corporations Will Suffer as Mucb], JOONGANG ILBO, Nov. 27, 1998, at 4; Seung-min Yoo, supra note 12 , at $18-19$.

${ }^{18}$ Outside directors or auditors, on the other hand, did not exist until recently. The Korea Stock Exchange ("KSE") required listed companies to elect one outside director in 1998 and to have outside directors comprise $25 \%$ of the board in 1999. See KSE, Securities Listing Regulations, art. $48-5$ (as amended Feb. 14, 1998). Previously, only certain public enterprises and financial institutions were required to have outside directors. See Public Enterprise Management Structure Improvement and Privatization Act, Law No. 5379 of 1997 (as amended Law No. 5690 of 1999), art. 5 Public Enterprise Management Structure Improvement and Privatization Act, Law No. 5379 of 1997 (as amended Law No. 5690 of 1999), art. 5; Presidential Implementing Decree, Decree No. 11395 of 1984 (as amended Decree No. 15513 of 1997), art. 12; Government Invested Institutions Management Act, Law No. 3690 of 1983 (as amended Law No. 5376 of 1997), art. 11. For a more in depth discussion of the adoption of the outside directors system in Korea, see Bok-ki Hong, Sa-woe-i-sa-jae-do-ui jung-chak-gwa ge bwal-sung-bwa [The Establishment and Promotion of an Outside Director System], 37 SANG-JANG-HYYP 7 (1998). 
criteria being personal loyalty to the principal shareholders. ${ }^{19}$ Those nominated for director and auditor positions were then universally approved at shareholders' meetings.

As a result, directors and auditors, thus held captive, could not act independently from principal shareholders in carrying out their respective functions. The board of directors did not make decisions on behalf of the corporation, but instead gave strong preference to the inclinations or passions of the principal shareholders. ${ }^{20}$ The failure of directors to perform their duties in an objective and fiducial manner had especially acute consequences under the Korean legal system, as directors in Korean corporations have a heightened responsibility due to their double function as officers. ${ }^{21}$ Auditors thus also failed to act as internal watchdogs monitoring the managerial decisions made by the board. ${ }^{22}$ Corporate decisions reflected the will of the principal shareholders. In the end, all of the central internal controls that were established under the KCC to monitor and manage corporate decision-making failed to operate.

19 See Hyo-sang Kang, supra note 16.

20 See Hyo-sang Kang et al., Gyung-young min-joo-bwa-ui gil (4): I-sa-bwoe. neun "Yes"-man-ba-neun gub-soo-gi [The Road to Management Democracy (4): Board of Directors Are a Rubber Stamp that Only Says 'Yes'], CHOSUN ILBO, May 14, 1996; Byung-tae Lee, I-sa-bwoe woon-yong-ui bwal-sung-bwa bang-an [A Proposal to Revive the Operation of the Board of Directors], 37 SANG-JANG-HYUP 139-141 (1998).

21 See Hee-chul Chung, Summary, supra note 6, at 49, 58; Yoo-suk Hong, Sa-woe-i-sa-jae-ui do-ip-bo-da-neun up-moo-dam-dang-i-sa-jae-ui pyae-ji-reul [Abolishing the Operation Director System Instead of Adopting an Outside Directors System], L. TIMES (Seoul), Apr. 9, 1998, at 6; Byung-tae Lee, supra note 20, at 13941; Jong-ho $\mathrm{Na} \&$ Young-shin Yoon, Chae-bol gae-hyuk (4) [Reform of the Chaebol (4)], CHOSUN ILBO, Jan. 5, 1998, at 11.

${ }_{22}$ See KCC art. 412; see also Dong-yoon Chung, supra note 13, at 358; Byung-tae Lee, supra note 20 , at 146 . Outside accounting audits, which are mandatory for listed companies, were ineffective because accountants were rarely held accountable. The Korean Supreme Court's 1997 decision that upheld a finding that Chongun Company, a major accounting firm, was liable for its improper accounting was considered one of the first of its kind. See Judgment of Sept. 12, 1997, Dae-bup-won [Supreme Court], 96 Da 41991; Hup Choi, Go-min-ba-neun bwoe-ge-bup-in [Worried Accounting Firms], CHOSUN ILBO, Sept. 21, 1997. Another egregious example of improper accounting involved the collapse of $\mathrm{Kia}$ Motors, when it was discovered that over three trillion won [U.S. $\$ 2.5$ billion] was not accounted for in their financial records. See Jung-jae Lee, 'Bbung-twi-gi' gwan-baeng-i bwoe-gae boo-sbil ki-wub ["Ballooning Practice Bred Improper Accounting], JOONGANG ILBO, Aug. 18, 1998. 


\subsection{Marginalized Nonprincipal Sharebolders}

Nonprincipal shareholders, on the other hand, played a marginal role in corporate affairs. Not only did they lack influence, but they also generally remained passive actors. First, a barrage of regulatory obstacles thwarted nonprincipal shareholders from more active participation in corporate policy. Most of the minimum holding requirements for exercising various shareholder rights were set at the prohibitively high level of five percent of the total issued stock, which effectively froze out many shareholders from participating in corporate affairs. ${ }^{23}$

With listed companies averaging 62.3 billion won (U.S. $\$ 52$ million) in capital stock in 1997, a five percent holding requirement, for instance, meant that interested stockholders would have to amass over 3.1 billion won (U.S. $\$ 2.6$ million) in shares to exercise their shareholder rights. ${ }^{24}$ This threshold requirement, therefore, served as an insurmountable obstacle for most small investors. Shareholder rights were seldom, if ever, exercised. ${ }^{25}$ One indicator of the difficulties shareholders experienced in taking action is that, until recently, meaningful shareholder litigation never existed in Korea. ${ }^{26}$ Institutional investors, on the other hand, who could have played a pivotal role, could not participate in corporate affairs because they were limited to shadow voting for customer accounts. ${ }^{27}$

One of the main reasons why policy makers kept the minimum holding requirements so high was because they wished to

${ }^{23}$ See Chul-song Lee, So-soo-joo-joo-gwon-ui shil-byo-sung gum-to [Review of the Effectiveness of Minority Sharebolder Rights], 35 SANG-JANG-HYUP 7 (1997).

${ }^{24}$ See KOREA LISTED CO. ASS'N, SANG-JANG-HWOE-SA-YON-GAM 1998 [LISTED COMPANIES ALMANAC 1998], 1998, at 53. All foreign exchange calculations in this Article are calculated at U.S. $\$ 1=1200$ won. This calculation was made on a par value basis; the actual market value would be, of course, even higher.

${ }^{25}$ See infra Section 3.3.

${ }^{26}$ See Dong-yoon Chung, Too-ja-ja-bo-bo-reul wui-ban so-song-jae-do-ae gwan-ban yon-goo [Research Paper on Litigation Procedures to Protect Investors], 35 SANG-JANG-HYUP 27 (1997); Chul-song Lee, supra note 23.

27 See Securities Investment Trust Business Act, supra note 1, arts. 25, 25-2; Securities Investment Company Act, supra note 1, art. 31; Jae-won Lee, Sangjang-bwoe-sa-ae it-sub-sub gi-gwan-too-ja-ja-ui yok-hal [The Role of Institutional Investors in Listed Companies], 17 COM. L. REV. 161, 167-77 (1998) (discussing the various limitations that institutional investors faced); Seung-il Hong \& Jung-jae Lee, Gi-gwan-too-ja-ga ji-boon-do joo-chong ui-gyul-gwon joo-gi-ro [Institutional Investors to be Granted Voting Rights], JOONGANG IIBO, Feb. 7, 1998, at 10. 
protect management. ${ }^{28}$ Policy makers believed that because management needed to make swift and decisive judgments, it could not be burdened by outside pressures such as shareholders. Concerns also existed that if minimum holding requirements were lowered, they would be abused by bad faith shareholders, and companies would be immobilized by an onslaught of litigation from disgruntled shareholders. ${ }^{29}$ Some also claimed that racketeers would acquire shares and threaten to cause trouble at shareholders' meetings, extorting payoffs in return for their cooperation. 'The recent increase in directors' liability insurance has been cited as another negative aspect and added expense of the new shareholding requirements. ${ }^{30}$

Given the Korean context, however, these arguments remain unpersuasive. First, natural barriers to litigation deter already nonlitigious Koreans. Litigation is time-consuming, expensive, and involves public exposure. Furthermore, Korea does not allow class action suits. ${ }^{31}$ The modified minimum holding threshold still requires a substantial sum of shares. With the average total market value of Korean listed companies at approximately 228 billion won (U.S. $\$ 190$ million), one percent of the total shares would require shareholders with 2.28 billion won (U.S. $\$ 1.9$ million) worth of stock to unite forces. ${ }^{32}$

${ }^{28}$ See Chul-song Lee, supra note 23. Management was also granted protection as a means to promote the newly established financial market because many companies were reluctant to list their shares on the market out of fear they would lose control. See Joon Park, Symposium: Capital Market and Financial Service in the Pacific Rim: Prospect for Harmonization, 28 LAW \& POL'Y INT'L BUS. 893 (1997). See generally JUNG-RYUM KIM, HAN-GOOK-GYUNGJAE-JUNG-CHEK 30-NYUN-SA [30 YEARS OF KOREAN ECONOMIC HISTORY] 278-84 (1995) (discussing the history of policies implemented to induce Korean companies to go public).

${ }_{29}$ See generally Korea Center for Free Enterprises (visited Sept. 1, 1999) < http://www.cfe.org > (discussing more in depth the potential problems of enhancing shareholder rights in Korea).

${ }^{30}$ See Joanna Slater, Running for Cover: Directors Seek Insurance Against Liability, FAR E. ECON. REV., Feb. 4, 1999, at 47 (discussing the increase to approximately 100 new policies in 1998 from practically none in 1997).

31 See Dong-yoon Chung, supra note 13 (discussing the need for Korea to adopt the U.S. class action system or the German Verbandsklage system). A draft law for class actions in securities-related cases has been presented to the National Assembly, but has yet to be adopted. See The National Assembly of the Republic of Korea (visited Nov. 1, 1999) <http://www.assembly.go.kr>.

32 See KSE, 368 Joo-shik [Stock] 12, Apr. 1999. 
Unlike Japan, the activity of racketeers has been marginal at best. ${ }^{33}$ Despite the recently lowered Securities Exchange Act ("SEA") threshold, there have been only a few reported shareholder derivative suits, all of which have occurred since $1997 .{ }^{34}$ The concerns about extortionist litigation have not materialized, and if any concerns still exist regarding extortion-oriented or bad faith litigation, many observers have pointed out that the courts can prevent such actions from taking place. ${ }^{35}$

When one weighs the consequences of an overprotective and unbridled management that lacks accountability versus the alleged need for speedy and decisive decision making, it appears that the government's overall policy intentions over the years have outlived their initial purpose.

Korean shareholders were also generally not interested in participating in corporate governance. Most shareholders, in fact, did not even realize that they had rights. ${ }^{36}$ The primary focus for Korean shareholders was short-term gains rather than long-term investment. ${ }^{37}$ This short-term investment strategy consequently led to little loyalty or interest in the affairs of corporate management. ${ }^{38}$

Nonprincipal shareholders, therefore, lacked the ability and interest to participate in corporate affairs. As testimony to the marginal role of shareholders, shareholders' meetings became symbolic events held according to predetermined scripts that

33 See Edward Lincoln, Behind the Chrysanthemum Curtain, ASIAN WALL ST. J., Nov. 19, 1997, at 12; Question Time in Japan, ECONOMIST, May 1, 1999, at 61 .

${ }^{34}$ Korea First Bank, Korea Telecom, and Samsung Electronics are the only recent examples. See infra Sections 4.3, 4.4; notes 180, 248; Chul-song Lee, supra note 23, at 7 ("[T] he Commercial Code provision governing derivative actions for practical purposes has been dead paper.").

${ }^{35}$ See Ki-won Choi, IMF ui geuk-bok-eul wui-ban sang-bup-gae-jung bangbyang (II) [How the Korean Commercial Code Should Be Amended to Overcome the IMF Situation (II)], L. TIMES (Seoul), Apr. 16, 1998, at 14; Gyo-chang Kim, Sang-bup-jung bwoe-sa-pyun-ui gae-jung-ui-gyun [An Opinion on Amending the Stock Corporation Section of the Commercial Code], L. TIMES (Seoul), Mar. 12, 1998, at 14.

${ }^{36}$ See Scourge of the Chaebol, ECONOMIST, Mar. 27, 1999, at 68.

37 For instance, the average length of ownership for individual investors was 1.2 months between January and July of 1999, 1.9 months in 1998, and 4.1 months in 1997. See KSE Press Release, Aug. 21, 1999 (on file with author).

${ }^{38}$ See infra Section 3.8 for further discussion on how the low dividend policy played an important role in the short-term investment strategy of most Korean shareholders. 
merely rubber-stamped major board decisions. ${ }^{39}$ In fact, the overall lack of protection for the interests of nonprincipal shareholders was considered to be one of the major barriers to foreign investment. ${ }^{40}$

\subsection{The Vulnerability of the Korean Corporate Paradigm: The Case of the Chaebols}

The results of this lapse in corporate regulation is best illustrated by the chaebol, or family-owned conglomerates, that maintain an overwhelming position in the Korean economy. ${ }^{41}$ First, as principal shareholders, the chieftains of Korea's chaebol conglomerates took full advantage of the lack of internal controls and checks and balances in Korean corporations. They dominated entire conglomerates and controlled dozens of subsidiaries and related companies while avoiding any accountability. ${ }^{42}$

These principal shareholders of the chaebol conglomerates usually held positions as "Chairmen," yet they would officially register themselves as directors in only the major corporations

${ }^{39}$ On the ineffectual nature of Korean shareholders' meetings, see ROGER L. JANELli \& DAWNHEE YIM, MAKING CAPITALISM: THE SOCIAL AND CULTURAL CONSTRUCTION OF A SOUTH KOREAN CONGLOMERATE (Stanford Univ. Press 1993); Chan-hyung Chung, supra note 14; Scourge of the Chaebol, supra note 36 ("Time was that shareholders' meetings in South Korea were about as rowdy as a party congress in the communist North; often the entire agenda was wrapped up in only a few minutes.").

40 See Soo-geun Oh, supra note 15.

41 See Mufson, supra note 10. The financial sector, which saw the collapse of such firms as Koryo Securities, Dongsuh Securities, Daedong Bank, Dongnam Bank, Kyunggi Bank, Chungchung Bank, Korea First Bank, and Seoul Bank, also serves as a prime example of the failed Korean corporate paradigm. See Schuman, Piling On, supra note 12; Michael Schuman, Tangled Web: Hanbo Steel Default Shows Shift in Government Policy, ASIAN WALI ST. J., Jan. 27, 1997, at 1 [hereinafter Schuman, Tangled Web]. See generally Ungki Lim, Patterns of Owership Structure and Their Characteristics in Korean Conglomerates: With Cases of the 30 Largest Chaebols (on file with author) (offering a comprehensive study of the ownership structure of the top 30 chaebols).

${ }_{42}$ See Chan-hyung Chung, supra note 14; Seung-wook Chung, Joo-sbikbwoe-sa ji-bae-joo-joo-ui bup-juk chaek-im-ae gwan-ban yon-goo [A Study on the Le. gal Liabilities of the Principal Shareholders in Corporations] (1998) (unpublished Ph.D. dissertation, Seoul National University) (on file with author) [hereinafter Seung-wook Chung, Sharebolders]; Seung-wook Chung, Dae-gi-up-ae it-subsub sa-shil-sang i-sa-ui chaek-im-gwa ge-ban-gye [The Responsibilities and Limitations of De Facto Directors in Large Corporations], 38 SANG-JANG-HYUP 91 (1998) [hereinafter Seung-wook Chung, Directors]. 
within the conglomerate. ${ }^{43}$ This overall structure allowed chieftains to minimize their legal responsibility. ${ }^{44}$ Chairmen, furthermore, reigned over conglomerates with only a marginal portion of the outstanding shares, often amounting to less than three percent. ${ }^{45}$ Companies within a conglomerate were instead held together through an interlocking web of cross shareholding ownership between related and sister companies. ${ }^{46}$ They avoided assuming legally binding positions and limited their personal investment risk while, at the same time, being the principal of the conglomerate.

Chairmen dominated directors and auditors. Nonprincipal shareholders, in turn, did not provide any monitoring pressure. Unlike the corporate governance systems in Japan or continental Europe, financial intermediaries failed to offer any supervisory discipline. ${ }^{47}$ The chance of being held accountable became remote, and investment risk exposure was minimal. Chaebol chairmen naturally gravitated to a business strategy that emphasized diversification, size, and market share over profitability and shareholder value. ${ }^{48}$ From this perspective, the interests of the en-

43 None of the leading cbaebols has been ever controlled by a woman.

44 See Seung-wook Chung, Directors, supra note 42.

${ }_{45}$ See KSE Press Release, Sept. 16, 1999 (on file with author). See generally Hee-kab Kang, Woo-ri-na-ra-ui Gi-up-ji-bae-goo-jo-ui ip-bup-ron-juk gum-to [Review of the Legislative Theory Behind Korea's Corporate Governance] 39 SANGJANG-HYUP 20, 28 (1999). To curb their influence, one observer has suggested limiting the voting rights of these principal shareholders. See Hee-chul Chung, Problems, supra note 6, at 12-13.

${ }^{46}$ In the case of the 10 largest chaebols, the principal stake of chaebol chairmen has in fact increased from $26.63 \%$ to $34.6 \%$ as a result of cross ownership and other family interests since the 1997 financial crisis. See KSE Press Release, supra note 45; Samuel Lee, Korean Conglomerates Remain Entrenched, N.Y. TIMES, Sept. 21, 1999. See generally Curtis J. Milhaupt, Property Rights in Firms, 84 VA. L. REV. 1145, $1162-63$ (1998).

47 See Coffee, supra note 4.

48 This overall corporate ownership structure can be traced to Korea's industrial policy. In an effort to industrialize the economy through cbaebol caglomerates, Korean policymakers believed that Korean corporations should be protected. See Namju Cho, Korea Takes New Step to Spur Mergers, ASIAN WALI ST. J., Mar. 20, 1997, at 1 (calling Korean corporations "often-coddled") [hereinafter Namju Cho, Korea Takes New Step]. But see The Apologist: The World Blames South Korea's Huge Conglomerates for the Country's Economic Meltdown-Bae Ie-Dong Has the Thankless Task of Defending Them, ECONOMIST, Aug. 29, 1998, at 62 (profiling an economist for thecbaebol's lobbying association who argues that the chaebol's excessive borrowing and emphasis on market share were necessary) [hereinafter The Apologist]. 
tire chaebol conglomerate were placed above the well-being of individual corporations and their respective shareholders. Dividends, for instance, were kept to a minimum.

In the initial stages, the chaebol model arguably held some advantages, such as efficient and speedy decision-making. ${ }^{49}$ Yet any management system that operates without adequate supervision or monitoring cannot remain internationally competitive. The longer such a system persists and the larger a company becomes, the greater will be the agency costs and the subsequent decline in efficiency. The chaebol's corporate structure exemplified these characteristics.

One person dominated all the companies in an entire conglomerate without any effective checks or balances or accountability. This management structure eventually became plagued with inefficiencies and irregularities. Chaebols often became nonspecialized, bloated behemoths that were largely sustained by debt. $^{50}$ At their worst, the conglomerate culture became conducive to illicit activities adverse to the interests of individual corporations and their respective shareholders. Funds from profitable companies were shifted to support new and weaker companies through transfer pricing and cross guarantees. ${ }^{51}$ More egregious examples included the expropriation of company funds, the creation of slush funds, and self-dealing by the principal shareholders. $^{52}$ To conceal these practices from shareholders and regula-

49 See Seung-min Yoo, supra note 12, at 13-15 (providing a comparison of the various asserted strengths and weaknesses of the chaebol's concentrated management style).

${ }^{50}$ See The Apologist, supra note 48 (discussing how the chaebols started going bankrupt as they became unable to pay interest charges on skyrocketing debts out of cash flow). The defunct Hanbo Steel was one of the most overleveraged companies in Korea before it collapsed, having amassed five trillion won in debt, over 22 times its equity. See Schuman, Tangled Web, supra note 41.

51 See infra Section 4.4.

52 See Mufson, supra note 10; Seung-min Yoo, supra note 12, at 17-18. Indicative of the state of mind of many chaebol owners, when charged with misappropriating customer funds, the former chairman of the defunct Kuhpyong Group replied at a National Assembly Audit Committee hearing, "I didn't know that you were not supposed to misappropriate customers' funds. . . . I didn't know which funds were the customers' and which were the company's." See Hee-chun Cho, Go-gaek-don yoo-yong bool-bup-in-jool mol-latda/Na seung-yul bwoe-jang gook-gam bal-ubn [Didn't Know It Was Illegal to Misappropriate Customer's Funds: Chairman Na Seung-yul Statement at National Audit Hearing], CHOSUN ILBO, Nov. 4, 1998, at 33. 
tors, opaqueness instead of transparency became the standard practice of choice. ${ }^{53}$ As chaebols became uncompetitive and vulnerable to outside shocks, the system began to unravel gradually, outliving most of the merits it once had.

The failure of corporate regulation, therefore, ultimately contributed to the spectacular failures of such mainstay conglomerates as Daewoo, Hanbo, Kia, and Daenong. ${ }^{54}$ Given the dominant position of the chaebol, their failures had multiple repercussions throughout the Korean economy and helped precipitate the severity of the 1997 financial crisis.

\section{THE NEW KOREAN COMMERCIAL CODE}

To correct these various structural problems, the KCC was amended three times in the past four years. The 1995 amendments came after more than ten years of review and became effective on October 1, 1996. The preamble of the $1995 \mathrm{KCC}$ provides that one of the primary purposes of the revisions was to "enhance the international competitiveness of Korean companies." 55 The major focus of the 1998 amendments was to address the failures that were exposed during the financial crisis. ${ }^{56}$ The 1998 amendments included provisions to simplify the mergers and acquisitions process, increase the accountability of de facto directors, and strengthen minority shareholder rights. The 1999 amendments, however, included regulations concerning stock options and audit committees. The various amendments that occurred in 1995, 1998, and 1999 will be reviewed by subject matter, with an emphasis on changes affecting corporate governance.

53 See Soo-geun Oh, supra note 15, at 73-74.

54 Among the top 30 major chaebol conglomerates, 11 have been taken over, have filed for bankruptcy, or are undergoing workout proceedings. The failed chaebols, along with their old rankings in parentheses, include Daewoo (2nd), Kia (8th), Halla (12th), Hanbo (14th), Jinro (19th), New Core (25th), Sammi (26th), and Dainong (34th). See Dong-han Lee, Shil-pae yon-gu: 2 sae chong-soo dok-dan-ae 'in-ui jang-mak' kka-ji [Study of Failure: From the Autocracy of Second Generation Chieftains to Being Sheltered by 'Curtains of People'], CHOSUN ILBO, Apr. 19, 1999, at 13.

$551995 \mathrm{KCC}$ preamble.

56 See 1998 KCC preamble. 


\subsection{Directors}

One of the main objectives of revising the $\mathrm{KCC}$ was to make directors more accountable. Under the previous legal regime, directors had an obligation to their company based on a general standard called the "duty of diligence as a good custodian (sunlyang-ban-gwan-li-ja-ui-ju-ui-ui-mu)," which was similar to a combination of the duty of good faith and fair dealing. ${ }^{57}$ This general standard was not based on a provision in the Commercial Code, but applied to corporate directors indirectly through reference to Article 681 of the Civil Code. ${ }^{58}$ Directors, in turn, neglected their roles as good custodians or fiduciaries. ${ }^{59}$ To heighten awareness of the fundamental responsibility that directors owe to their corporations, an explicit fiduciary duty has now been imposed upon directors. ${ }^{60}$ Under this provision, directors must fulfill their obligations in a fiduciary manner on behalf of the company as provided by the law, as well as by the articles of incorporation. ${ }^{61}$

Secondly, the new KCC requires directors to act more vigilantly in protecting the interests of their company. Directors now have a duty to immediately report to the company's statutory auditor any facts they learn that may "significantly injure" the company. ${ }^{62}$ This provision affirmatively forces directors to be more attentive in protecting the interests of shareholders. The potential effectiveness of this new duty, however, will depend on how the courts interpret the term "significant injury." (Similarly, the board of directors' minutes must now include the names of any directors that objected to any decisions, and the reasons why they objected. ${ }^{63}$ Not only did directors rarely object to board decisions, but board minutes rarely provided any detailed informa-

$57 \mathrm{Ki}$-won Choi, supra note 1. Some believe that, other than symbolically, the fiduciary duty and the general due diligence standards are not significantly distinguishable, and propose instead that Korea follow the German model, placing the burden of proof on directors to properly carry out their duties. See id.

${ }^{58}$ See KCC art. 1 (providing that the Civil Code applies when a matter is not covered by the $\mathrm{KCC}$ ).

59 See infra Section 4 for various examples.

60 See 1998 KCC art. 382-3.

61 See id.

621995 KCC art. 412-2.

63 See 1999 KCC art. 391-3. Creditors can no longer inspect board minutes. See id. art. 396. 
tion concerning any objections in the past. At the same time, companies may now reject a shareholder's inspection request if they provide a "reason." If rejected, the shareholder must obtain court approval for an inspection, placing the burden on the shareholder, rather than the company.)

Thirdly, another significant amendment to the KCC is that principal shareholders now may be considered to have the same responsibilities and liabilities as directors under certain circumstances. Under the old regulatory framework, it was extremely difficult to establish liability against principal shareholders. ${ }^{65}$ One would have to either demonstrate that the principal shareholders were de facto directors or pierce the corporate veil-both challenging tasks, given that the party making such an assertion has the burden of proof. ${ }^{66}$

The new KCC therefore provides that persons who "use their influence to direct or participate in the corporate affairs of directors" can be held jointly and severally liable with the other directors of a company. ${ }^{67}$ Persons who hold titles such as "honorary chairman," "chairman," "president," "vice-president," or conduct corporate affairs under the pretext of such titles, in particular, will be deemed to be directors even if they are not registered directors. ${ }^{68}$ The principal shareholders who have dominated corporate decision-making can no longer avoid managerial liability merely by not registering as directors. This new provision makes it substantially easier to find principal shareholders accountable as directors. ${ }^{69}$ They will be considered the same as other directors

64 See id. art. 391-3; art. 396.

65 See Seung-wook Chung, Sharebolders, supra note 42.

66 See Seung-wook Chung, Directors, supra note 42, at 96-97; see also Judgment of June 11,1985, Dae-bup-won [Supreme Court], 84 Daka 963 (finding that under Article 395, a person does not have to be a registered director to be considered a de facto representative director that could bind the company).

$671998 \mathrm{KCC}$ art. 401-2.

68 See id. art. 401-2, para. 1, subpara. 3.

69 Minority shareholders of Korea Telecom recently brought a case against the government claiming that the government should be responsible under this provision because it in fact dictated corporate affairs at Korea Telecom. See Insoon Kim, Han-gook-tong-shin so-aek-joo-joo, jung-boo-ae joo-joo-dae-pyo-so-song [Korea Telecom Minority Sharebolders Bring a Sharebolder Derivative Action Against the Government], MAEIL BUS. NEWS (Seoul), Apr. 12, 1999. 
with the same duties and responsibilities. As a result, many company chieftans are finally registering as directors. ${ }^{70}$

The new KCC amendments also seek to accommodate the interests of small companies. First, corporations having less than 500 million won (U.S. $\$ 418,000$ ) in paid-in capital, for example, do not have an obligation to elect a minimum of three directors. ${ }^{71}$ This new provision allows small corporations to avoid the unnecessary burden of electing ghost directors who only lend their name during the process of incorporation but do nothing else, a common practice in the past. ${ }^{72}$ If a small corporation elects only one director, all occasions where the $\mathrm{KCC}$ requires approval from the board of directors will require instead approval from the shareholders. ${ }^{73}$

Finally, to enhance the efficiency of the board of directors, several changes have been made. The entire board may now delegate certain functions to a subcommittee of directors. ${ }^{74}$ Those functions that cannot be delegated include such matters as the election or termination of the representative director and the proposal of issues that require shareholder approval. Furthermore, unless provided otherwise in the articles of incorporation, directors may now participate in board meetings through simultaneous audiovisual electronic transmission. ${ }^{75}$

\subsection{Auditors and Audit Committees}

One of the most dubious positions in a Korean corporation belongs to that of statutory auditors. ${ }^{76}$ Auditors were established

70 See Jong-young Kim, Geu-rup-bwoe-jang-jae pye-ji... joo-ryuk-sa gyungyoung jip-joong [Abolishing of the Conglomerate Chairman System... Concentrating Management of Main Companies], MAEIL BUS. NEWS, Feb. 28, 1998.

71 See 1998 KCC art. 383.

72 For a critical view of this amendment, see Ki-won Choi,supra note 35.

73 See 1998 KCC art. 383, para. 4.

74 See 1999 KCC art. 393-2.

75 See id. art. 391.

76 See Chan-hyung Chung, supra note 14, at 14-15; see also Joon-young Chung, Gi-up-gyung-young-too-myung-sung jae-go-wa gam-sa-jae-do gae-sun [Enbancing Corporate Management Transparency and Improving the Audit System], 35 SANG-JANG-HYUP 76 (1997). Auditors are separated into internal auditors and external auditors. External auditors are limited to accounting audits and are required for all companies with more than seven billion won (U.S. \$5.8 million in total assets under the Law Concerning External Audits of Corporations, Law No. 3297 of 1980 (as amended Law No. 6108 of 2000). Internal auditors are governed under the KCC. See KCC arts. 409-415; see also Young-il 
as internal institutions to monitor corporate affairs and the decision making of directors on behalf of shareholders, ${ }^{7}$ yet they were unable to fulfill their function. The recent amendments seek to strengthen the authority of auditors so they can effectively act as internal watchdogs, as intended under the Commercial Code. For instance, companies can now establish an audit committee to replace the functions of the auditor. ${ }^{78}$

First, to enhance their standing, auditors will receive protection from unjust termination. ${ }^{79}$ Auditors commonly feared retaliatory discharge if they raised any challenges against management in the interests of the corporation or its shareholders. To allay these concerns, auditors now have a guaranteed opportunity to inform all shareholders of the circumstances of their termination.

Auditors also have been empowered with the right to convene a shareholders' meeting. ${ }^{80}$ In the past, only the board of directors or shareholders who met a high holding requirement could call a shareholders' meeting. Auditors, especially outside auditors who are required for large companies, have gained tremendous authority as a result of this provision. ${ }^{81}$ They can unilaterally call shareholders' meetings in order to inform shareholders, take votes on controversial issues, and confirm board decisions.

Finally, the term of office for auditors has been extended from two years to three years, in order to match the length of the term for directors. ${ }^{82}$ It was believed that longer terms would provide auditors more job security and more independent authority.

In addition to granting these various protections, the new KCC limits the qualifications of auditors to guarantee their objectivity. An individual can no longer be both an auditor of a parent company and a director of a subsidiary company at the same

Yoo, Sang-geun-gam-sa-wa sa-woe-gam-sa-jae-do-ui do-ib-ui-ui-wa woon-yong-byoyul-bwa bang-an [The Importance of Adopting, and Improving the Management Effectiveness of, Permanent Auditors and the Outside Auditor System], 37 SANGJANG-HYUP 42 (1998).

77 See KCC art. 412; see also Dong-yoon Chung, supra note 13, at 358.

78 See $1999 \mathrm{KCC}$ art. 415-2.

79 See $1995 \mathrm{KCC}$ art. 409-2.

80 See id. art. 412-3.

81 See infra Section 4.4.

82 See 1995 KCC art. 410. The term of office for auditors was extended from one year to two years in 1984. See Ju-chan Sonn, Reflections, supra note 6 , at 34 . 
time. ${ }^{83}$ Parent company directors tend to have a strong influence over the directors of a subsidiary. Absent this position, auditors of a parent company could have a conflict of interest when auditing decisions made by the parent company's directors concerning their influence over a subsidiary's directors. If auditors of a parent company were jointly allowed to be directors of a subsidiary, they would be forced to audit affairs relating to themselves. ${ }^{84}$ In contrast, a person may be an auditor of both a parent and a subsidiary company, or a director of a parent company and an auditor of a subsidiary company without implicating conflict of interest concerns.

If an audit committee is established based on the terms of a company's articles of incorporation, the committee must consist of at least three directors. ${ }^{85}$ In electing audit committee members, the committee cannot consist of more than one-third of the following categories: (1) an inside director or a person who was an inside director within the last two years; (2) the largest shareholder, his or her spouse, or direct lineal relative; (3) a director, auditor, or employee of the largest corporate shareholder, a parent or subsidiary company, or a major interested company; (4) a spouse or direct lineal relative of a director; and (5) a director, auditor or employee of another company for which the director also acts as a director. Furthermore, audit committee members can only be terminated by a vote of over two-thirds of the board of directors. These various requirements were stipulated to ensure the independence of the audit committee.

\subsection{Strengthening Shareholder Rights}

Among the various amendments to the KCC, some of the most significant changes involved the new measures to strengthen the neglected rights of shareholders. The $1995 \mathrm{KCC}, 1998 \mathrm{KCC}$, and $1999 \mathrm{KCC}$ sought to make it easier for shareholders to exercise their existing rights and also sought to establish new rights on their behalf. These changes led to a seismic shift in the overall scheme of corporate regulation.

83 See 1995 KCC art. 411; see also Ju-chan Sonn et al., Sang-bup-gae-jung-anbae-sul [Explanatory Notes on Proposed Amendments to the Commercial Code] 139 (Bupmoonsa Publishers 1995) [hereinafter Explanatory Notes].

${ }^{84}$ See Explanatory Notes, supra note 83, at 139.

85 See 1999 KCC art. 415-2. 
Table 1: Recent Amendments to the KCC and SEA $A^{86}$

\begin{tabular}{|c|c|c|c|c|c|c|}
\hline \multirow{2}{*}{$\begin{array}{c}\text { Shareholder Right } \\
\text { Type }\end{array}$} & \multicolumn{2}{|c|}{ KCC } & \multicolumn{4}{|c|}{ SEA } \\
\hline & $1995^{87}$ & $1998^{88}$ & $1997^{89}$ & $\begin{array}{c}\text { Feb. } \\
1998^{90}\end{array}$ & $\begin{array}{c}\text { May } \\
1998^{91}\end{array}$ & Jan. $2000^{92}$ \\
\hline $\begin{array}{l}\text { Requesting } \\
\text { termination of } \\
\text { directors \& } \\
\text { auditors }\end{array}$ & $5 \%$ & $3 \%$ & $\begin{array}{c}1 \% \\
(0.5 \%)\end{array}$ & $\begin{array}{c}0.5 \% \\
(0.25 \%)\end{array}$ & $\mathrm{N} / \mathrm{C}$ & $\begin{array}{c}0.25 \% \\
(0.125 \%)\end{array}$ \\
\hline $\begin{array}{l}\text { Seeking injunctive } \\
\text { action against } \\
\text { illegal acts }\end{array}$ & $5 \%$ & $1 \%$ & $\begin{array}{c}1 \% \\
(0.5 \%)\end{array}$ & $\begin{array}{c}0.5 \% \\
(0.25 \%)\end{array}$ & $\mathrm{N} / \mathrm{C}$ & $\begin{array}{c}0.25 \% \\
(0.125 \%)\end{array}$ \\
\hline $\begin{array}{l}\text { Bringing share- } \\
\text { holder derivative } \\
\text { actions }\end{array}$ & $5 \%$ & $1 \%$ & $\begin{array}{c}1 \% \\
(0.5 \%)\end{array}$ & $0.05 \%$ & $0.01 \%$ & $0.005 \%$ \\
\hline $\begin{array}{l}\text { Convening a spe- } \\
\text { cial shareholders' } \\
\text { meeting }\end{array}$ & $5 \%$ & $3 \%$ & $\begin{array}{c}3 \% \\
(1.5 \%)\end{array}$ & $\mathrm{N} / \mathrm{C}$ & $\mathrm{N} / \mathrm{C}$ & $\begin{array}{c}1.5 \% \\
(0.75 \%)\end{array}$ \\
\hline $\begin{array}{l}\text { Compelling } \\
\text { production of } \\
\text { financial records } \\
\text { for inspection }\end{array}$ & $5 \%$ & $3 \%$ & $\begin{array}{c}3 \% \\
(1.5 \%)\end{array}$ & $\begin{array}{c}1 \% \\
(0.5 \%)\end{array}$ & $\mathrm{N} / \mathrm{C}$ & $\begin{array}{c}0.5 \% \\
(0.25 \%)\end{array}$ \\
\hline $\begin{array}{l}\text { Appointing an } \\
\text { inspector to exam- } \\
\text { ine corporate af- } \\
\text { fairs, records, \& } \\
\text { financial status }\end{array}$ & $5 \%$ & $3 \%$ & $\begin{array}{c}3 \% \\
(1.5 \%)\end{array}$ & N/C & $\mathrm{N} / \mathrm{C}$ & $\begin{array}{c}1.5 \% \\
(0.75 \%)\end{array}$ \\
\hline $\begin{array}{l}\text { Terminating a } \\
\text { liquidator }\end{array}$ & $5 \%$ & $3 \%$ & $\begin{array}{c}3 \% \\
(1.5 \%)\end{array}$ & $\begin{array}{c}0.5 \% \\
(0.25 \%)\end{array}$ & $\mathrm{N} / \mathrm{C}$ & $\begin{array}{c}0.25 \% \\
(0.125 \%)\end{array}$ \\
\hline $\begin{array}{l}\text { Requesting cumula- } \\
\text { tive voting }\end{array}$ & - & $3 \%$ & - & - & - & - \\
\hline $\begin{array}{l}\text { Making a share- } \\
\text { holder proposal }\end{array}$ & $\overline{-}$ & $3 \%$ & $\begin{array}{c}1 \% \\
(0.5 \%)\end{array}$ & $\bar{N} / \mathrm{C}$ & $\mathrm{N} / \mathrm{C}$ & $\begin{array}{c}0.5 \% \\
(0.25 \%)\end{array}$ \\
\hline $\begin{array}{l}\text { Requesting } \\
\text { dissolution }\end{array}$ & $10 \%$ & $10 \%$ & - & - & - & - \\
\hline
\end{tabular}

${ }^{86}$ The numbers in parentheses apply to listed or registered companies with at least 100 billion won in paid-in capital. SEA applies to shareholders with at least six months ownership. January 2000 revisions to the SEA only apply to certain securities companies with at least two trillion won in assets. N/C signifies no change.

87 KCC, as amended by Law No. 5053 of 1995 (effective Oct. 1, 1996).

${ }^{88} \mathrm{KCC}$, as amended by Law No. 5591 of 1998 (effective Dec. 28, 1998, except for the cumulative voting provision, which became effective on June 28 , 1998).
89 SEA, as amended by Law No. 5254 of 1997 (effective Apr. 1, 1997).
90 SEA, as amended by Law No. 5521 of 1998 (effective Apr. 1, 1998).
91 SEA, as amended by Law No. 5539 of 1998 (effective May 25, 1998).
92 SEA, as amended by Law No. 6176 of 2000 (effective Apr. 1, 2000). 
First and foremost, although the minimum holding requirements for exercising various shareholder rights remain high, ${ }^{93}$ considerable progress has been achieved in that these requirements were significantly lowered. Overall, the new KCC has reduced the minimum holding standards required to exercise the following rights: ${ }^{94}$ (1) requesting a court to terminate directors and auditors for improper or illegal acts in contravention of any law or the articles of incorporation, reduced from five percent to three percent; ${ }^{95}$ (2) seeking injunctive action against illegal acts in contravention of any law or the articles of incorporation of a director, reduced from five percent to one percent; ${ }^{96}$ (3) bringing shareholder derivative actions, reduced from five percent to one percent; ${ }^{97}$ (4) convening a special shareholders' meeting, reduced from five percent to three percent; ${ }^{98}(5)$ compelling production of financial records for inspection, reduced from five percent to three percent; ${ }^{99}(6)$ requesting a court to appoint an Inspector to examine corporate affairs, corporate records, and financial status, reduced from five percent to three percent; ${ }^{100}$ and $(7)$ terminating a liquidator, reduced from five percent to three percent. ${ }^{101}$

As noted above, it is now easier for shareholders to seek the termination of a director. In the past, when a director committed an "improper act," or violated "a law or the articles of incorporation," shareholder attempts to terminate such a director were often stymied at the shareholders' meeting due to the dominance of the principal shareholders. ${ }^{102}$ Dissenting shareholders with only

93 The holding requirements for shareholders of listed companies were first lowered at the end of 1996. See SEA, Law No. 5254 of 1997; supra Table 1.

94 This summary of percentages excludes shares that do not have voting rights, such as most preferred shares. For a summary of litigation-related investor rights, see Dong-yoon Chung, supra note 26, at 41-42.

${ }_{95}$ See 1998 KCC art. 385.

96 See id. art. 402.

97 See id. art. 403.

98 See id. art. 366.

99 See id. art. 466. Ki-won Choi argues that since shareholder derivative suits are in fact impossible without the right to inspect financial records that these two rights should have the same requirement of one percent. See Ki-won Choi, supra note 35.

100 See $1998 \mathrm{KCC}$ art. 467.

101 See id. art. 539.

102 Id. art. 385. 
three percent of the total shares can now request the termination before a competent court after such a shareholders' meeting. This provides an important means by which to hold directors more accountable, especially those protected by the dominant shareholder.

In the case of the shareholder derivative action, the new law not only lowered the holding requirement, but also added a critical feature. ${ }^{103}$ Under the new law, the one percent holding requirement for bringing a derivative action only has to be met when the action commences and need not be maintained for the duration of the case. This change greatly facilitates the ability of small investors to sustain derivative actions, especially because most investors in Korea do not hold onto their shares for extended periods. ${ }^{104}$ Overall, the lower minimum ownership requirements mark an important step in empowering shareholders to oversee the actions of directors. As a result, the number of shareholder actions has risen significantly. ${ }^{105}$

In addition to lowering the various holding requirements, both the 1998 and 1999 amendments established several new shareholders' rights. First, as provided in the articles of incorporation, shareholders can now execute their votes in writing without actually attending the shareholders' meeting. ${ }^{106}$ This makes it substantially easier for shareholders to exercise their rights. Second, shareholders can request cumulative voting when electing directors. ${ }^{107}$ Shareholders with at least three percent of the total shares can request cumulative voting when more than two directors are elected. Companies must accept such a request unless they have added a provision in their articles of incorporation to exclude it. Amending the articles of incorporation requires a spe-

\footnotetext{
103 See id. art. 403, para. 5.

104 See KSE Press Release, supra note 37.

105 See infra Section 4.

106 See 1999 KCC art. 366-3.

107 See $1998 \mathrm{KCC}$ art. 382-2. One observer argues that Korea is not ready for the cumulative voting system because it will create confusion. See Ki-won Choi, supra note 35. Choi proposes instead a new system of corporate governance whereby $50 \%$ of the board would be elected as before, $25 \%$ would be elected with each shareholder's voting rights being limited to a maximum of $3 \%$, and the remaining $25 \%$ would be elected by large creditors. See id. For companies with more than 10,000 workers, a representative from the workers would be elected. See id.
} 
cial majority vote at a shareholders' meeting, which may be a considerable burden. ${ }^{108}$

One problem with this provision is that, unlike the other provisions of the $1998 \mathrm{KCC}$, it did not become effective until June 28, 1999. Any election of directors preceding that date did not have to be executed with cumulative voting, and companies were granted a chance to adopt exclusionary provisions to prohibit it. According to the Korea Stock Exchange, of the 516 listed companies with fiscal years ending in December 1998, 386 companies, or $74.8 \%$, managed to enact provisions excluding cumulative voting. ${ }^{109}$ The remaining 130 companies, or $26.2 \%$, and those companies that have not adopted such exclusionary provisions by June 1999, will have to adopt cumulative voting.

Another important right created for shareholders is the right to propose items to be placed on the agenda of a shareholders' meeting. ${ }^{10}$ Interested shareholders with at least three percent of the total issued shares must first submit their proposals to the responsible director six weeks before the shareholders' meeting. Shareholders can request that their proposal items be included along with other material and notices sent to other shareholders. The board of directors must accept a shareholder proposal thus

108 See infra note 118 and accompanying text.

109 See Yoon-jae Han, 12 wol gyol-san-bup-in 75\% jib-jung-tu-pyo-jae do-ip anki-ro [75\% of Companies with Fiscal Years Ending in December Decide Not to Adopt Cumulative Voting], CHOSUN ILBO, Mar. 30, 1999; Sung-won Lee, Daeduk-san-up deung 22 sa aek-myun bun-bal: 12 wol bup-in jung-gwan byun-gyung [Companies with Accounting Years Ending in December Change Articles of Incorporation: Daeduk Industries and 22 Other Companies Provide for Stock Splits], MAEIL BUS. NEWS, Mar. 30, 1999. Citing the situation in Japan, Ki-won Choi predicted that companies would just pass provisions to exclude the requirement or would elect directors on staggered terms. See Ki-won Choi, supra note 35.

110 See $1998 \mathrm{KCC}$ art. 363-2. The first reported case where a company accepted a shareholder proposal occurred on May 27, 1997, when Korea International Merchant Bank accepted a proposal to elect certain directors. See Sung-il Hong, So-aek joo-joo jae-an chut gwan-chul [Minority Sharebolder Proposal Accepted for the First Time], JOONGANG ILBO, May 28, 1997. See generally Hongryul Chun, Ju-ju-jae-an-jae-do-wa sang-jang-gi-up-ui dae-ung [The Shareholder Pro. posal and How Listed Companies Should Respond], 38 SANG-JANG-HYUP 69 (1998); Jong-ho Kwon, Gyung-young-ja-gam-shi-soo-dan-eu-ro-sub wui-im-janggwon-yu-ui byo-yul-sung [Effectiveness of Proxy Solicitation as a Means of Monitoring Management], 17 COM. L. REV. 111 (1998). Shareholder proposals were adopted for listed companies at the end of 1996. See SEA, supra note 93. 
submitted unless it contravenes a law or the articles of incorporation. ${ }^{111}$

Those who make a shareholder proposal may then request an opportunity to explain their proposal at the shareholders' meeting. ${ }^{112}$ Companies that fail to comply with the shareholder proposal provision may be subject to a fine of up to five million won (U.S. \$41,800). ${ }^{13}$ This vital provision grants shareholders the opportunity to voice their opinions on issues of concern to them, instead of merely being limited to the agenda set by the company.

This provision is flawed, however, because it is not consistent with the procedures by which to convene a shareholders' meeting. A company only has to give shareholders two weeks' notice before convening a shareholders' meeting. ${ }^{114}$ Hence, if shareholders receive only the minimal two weeks' notice, they will not have sufficient time to submit a shareholder proposal, which requires six weeks' advance notice. This means that the shareholder proposal provision can only be used if the shareholders themselves request a special shareholders' meeting. Otherwise, for shareholders' meetings convened by the board of directors, shareholders can only guess when the actual meetings will be held and submit shareholder proposals six weeks in advance of that estimated date. One company has already used this loophole, rescheduling a shareholders' meeting to avoid including a shareholder proposal made by several foreign funds. ${ }^{115}$

\subsection{Mergers}

Another important reason for amending the $\mathrm{KCC}$ was to overhaul the regulations concerning mergers. As testimony to the significance of mergers, the merger provisions, originally part of "Section 10 Dissolutions" under the old KCC, were moved to a newly created section specifically entitled "Section 10 Mergers" in the $1998 \mathrm{KCC}$. From one perspective, a more active mergers and acquisitions market was viewed as a means of strengthening

111 See 1998 KCC art. 363-2, para. 3.

112 See id.

113 See id. art. 635, para. 1, subpara. 19-3.

114 See KCC art. 363.

115 See Jin-gun Chung, Mi-gook-gye fund, Nong-shim-ae aek-myun-boon-bal yo-goo [American Fund Requests Stock Split from Nongshim], MAEIL BUS. NEWS, Aug. 24, 1998. 
corporate governance. ${ }^{116}$ The lack of such external discipline was one reason why principal shareholders could maintain low share ownership and minimal risk exposure while dominating corporate affairs. The new provisions were also considered a means to facilitate corporate restructuring efforts. Overall, the amendments of the merger section sought to streamline the merger procedures, enhance the protection of shareholders, and assure adequate protection for management. ${ }^{117}$

\subsubsection{Streamlining Merger Procedures}

Various procedural modifications were made to facilitate the merger process. First, the special majority voting procedure required for special resolutions, such as mergers or other major corporate changes, was modified. ${ }^{118}$ Many public companies had trouble meeting the quorum requirement for special resolutions, which called for attendance at the shareholders' meeting by the shareholders of at least one-half of all shares entitled to vote. ${ }^{119}$ The special majority voting procedure now provides that a merger may be approved with just a two-thirds vote of the shareholders who attend the shareholders' meeting. To ensure some degree of representativeness, this two-thirds vote must consist of at least one-third of the total shares entitled to vote. Thus, the original mandatory quorum requirement for voting on a special resolution was replaced with a simpler "voting quorum."

116 See Namju Cho, Korea Takes New Step, supra note 48.

117 See Dong-yun Chung, Hwoe-sa-ui bap-byung-jul-cha-ui gan-so-bwa-wa joojoo-ui bo-bo [The Simplification of Merger Procedures and the Protection of Share. holders], Public Hearing on the Amendments to the Commercial Code, Ministry of Justice, Apr. 1, 1998, at 11. This shareholder proposal right existed for listed companies under the Securities Exchange Law and was first exercised by shareholders of Korea International Merchant Bank in April 1997. See Gwangjin Oh, Han-woi-jong-geum no-jo geum-yung-gwon chut joo-joo-jae-an-gwon bengsa [Korea International Merchant Bank Labor First to Exercise Sharebolder Pro. posal Right in Financial Industry], KOREA ECON. DAILY, Apr. 15, 1997.

118 See $1995 \mathrm{KCC}$ art. 434. Previously, the quorum requirement for"special resolutions" called for the attendance of shareholders representing at least one-half of the total voting shares and a two-thirds approval among them. Because this quorum normally could not be met, unvoted shares that were deposited with the Korean Deposit Agency would be counted through shadow voting toward the quorum requirement. See SEA art. 174-6; see also Explanatory Notes, supra note 83, at 151-53.

119 Once the quorum is met, special resolutions require the approval of at least two-thirds of the total shares actually attending the shareholders' meeting. See KCC art. 434. 
Another change to the new merger regulations allows companies to dispense with the final reporting requirements to shareholders. ${ }^{120}$ Under the previous provisions, after a merger was approved, but before the final merger registration, the board of directors had to prepare a final report to shareholders at a special shareholders' meeting regarding all matters relating to the proposed merger. ${ }^{121}$ The drafters of the $1995 \mathrm{KCC}$ believed that calling a shareholders' meeting solely for this purpose was unnecessary, especially because shareholders would have already approved the merger, and the merger could not be undone or changed at that time. ${ }^{122}$ Therefore, under the new procedures, the drafters provided that the company may instead disclose any information regarding the merger according to the public notice requirements in the company's articles of incorporation. ${ }^{123}$

From another perspective, new mergers and acquisitions regulations were also needed to help desperate companies restructure and attract capital following the credit crunch of the financial crisis. Many companies at the time sought to merge failing or weaker subsidiaries with sister companies. One way to facilitate corporate restructuring was the adoption of a short-form merger procedure and a small-scale merger procedure.

Established in 1995, the short-form merger procedure was further modified under the $1998 \mathrm{KCC} .{ }^{124}$ Certain companies being acquired can use the short-form merger procedure to substitute the mandatory shareholder approval process with the mere acceptance of the board of directors. The short-form merger can be used where the acquiring company purchases more than ninety percent of the target company's stock or if all of the target company's shareholders agree to adopt the procedure. ${ }^{125}$ Short-form mergers, therefore, allow companies to dispense with the requirement of convening a separate shareholders' meeting for ap-

120 See $1995 \mathrm{KCC}$ art. 526; $1998 \mathrm{KCC}$ art. 527.

121 See Explanatory Notes, supra note 83, at 195.

122 See id. at 196.

123 See KCC art. 289.

124 See 1995 KCC art. 522; 1998 KCC art. 527-2.

125 See $1998 \mathrm{KCC}$ art. 527-2. Under the old article 522 of the $1995 \mathrm{KCC}$, when the short-form merger procedure was first established, the acquiring company had to acquire $100 \%$ of the target company's shares or receive an approval by all of the target company's shareholders. 
proval. Subsidiaries controlled by parent companies, for instance, can be absorbed in a simplified manner.

The new KCC also introduced a small-scale merger procedure so that large acquiring companies could purchase smaller companies more easily. According to Article 527-3, a large acquiring company can use the small-scale merger when it issues less than five percent of its total shares to purchase a small company. ${ }^{126}$ In small-scale mergers, the large acquiring company does not have to obtain shareholder approval through a separate shareholders' meeting. Such a meeting was deemed unnecessary because, given the relatively small size of the purchase, the acquisition would not affect the company substantially. ${ }^{127}$

Finally, to accelerate the merger process, two approval deadlines were shortened. First, the time period allowed for creditors to object to mergers has been reduced from a minimum of two months to a minimum of one month. ${ }^{128}$ Second, the new amendments reduce the time needed to merge stock from three months to one month. ${ }^{129}$

\subsubsection{Protecting Minority Sharebolders' Interests}

While the new KCC simplified various merger procedures to facilitate the corporate restructuring process, it also sought to guarantee that this general deregulation did not infringe on the interests of shareholders. ${ }^{130}$ Therefore, various shareholder rights and disclosure requirements were concomitantly strengthened to protect shareholders.

First, under the $1998 \mathrm{KCC}$, various documents must be made available for inspection at the company's headquarters. During the period extending from two weeks before the convening of the shareholders' meeting to approve the merger, to six months after the actual merger, the following documents must be made avail-

126 See 1998 KCC art. 527-3.

127 Recent examples of small-scale mergers have involved Kangwon Industries, Tong Yang Cement, Orion Electric, Han II E Wha, and Hyundai Engineering and Construction merging subsidiary or related companies.

128 See $1998 \mathrm{KCC}$ art. 527-5.

129 See $1995 \mathrm{KCC}$ art. 440.

130 For a discussion on how minority shareholders need further protection, see Hyun-yoon Shin, Sang-bup-sang gi-up-gyul-bap-ui sa-jun-tong-jae-wa moon-jaejum [The Prior Controls, and Their Problems, in Corporate Consolidation under the Commercial Code], 18 COM. L. REV. 51 (1999). 
able to shareholders: the merger agreement, the final balance sheets and profit and loss statements of the respective companies, and a document explaining the allocation of shares to the target company's shareholders. ${ }^{131}$

Subsequently, the board of directors must provide additional post-merger disclosure. For a period of six months after the merger, the directors must also provide information concerning the status of objecting creditors, the total assets and liabilities assumed from the target company, the date of the merger, and other information related to the merger. ${ }^{132}$ This information must be made available to shareholders for inspection at the company's headquarters.

In the case of short-form mergers, the target company's shareholders must be notified within two weeks that a merger is proceeding without a shareholders' meeting. If they desire, the target company's shareholders can, of course, waive this notice requirement. ${ }^{133}$ The notice may be given through the public notice process or through direct notice to individual shareholders.

Finally, to use the small-scale merger procedure, the large acquiring company must state in the merger agreement that it did not convene a formal shareholders' meeting. The large acquiring company must also alert shareholders to the acquired company's name, location of its headquarters, and the date of the merger through either a public notice or individual notification. ${ }^{134} \mathrm{How}-$ ever, a large acquiring company cannot use the small-scale merger procedure if it has to pay more than two percent of its net assets to purchase the small target company's shares. ${ }^{135}$ Shareowners who own more than twenty percent of the total shares can also demand that the acquiring company use the normal merger procedure instead of the small-scale procedure. ${ }^{136}$ Furthermore, shareholders who object to the small-scale merger may request appraisal rights. ${ }^{137}$

\footnotetext{
131 See $1998 \mathrm{KCC}$ art. 522-2.

132 See id. art. 527-6.

133 See id. art. 527-2.

134 See id. art. 527-3.

135 See id. para. 1.

136 See id. para. 4.

137 See id. para. 5.
} 


\subsubsection{Accommodating Management Concerns}

The simplification of the mergers procedures also raised concerns among companies about the threats of hostile takeovers. ${ }^{138}$ In response to these concerns, anyone that acquires more than ten percent of the issued stock of another company must, in due course, notify that company of their new ownership position to provide sufficient notice to that company. ${ }^{139}$ This ten percent disclosure rule was enacted to give fair warning so that threatened companies would have an opportunity to defend themselves. In particular, the effectiveness of this rule will depend on whether acquisitions by related and interested shareholders will be effectively combined when calculating the ten percent threshold to prevent circumvention.

As an ultimate means of protection, lawmakers granted companies the ability to restrict the transfer of shares. ${ }^{140}$ A company can require stockholders to obtain the board of directors' approval before they sell their shares. This restriction was added so that closed corporations could maintain "mutual trust between shareholders" by preventing unwanted shareholder participation. ${ }^{141}$ It is therefore only supposed to apply to closed corporations and not to listed or public corporations. ${ }^{142}$ This restriction only applies to newly issued shares and must be stated in the articles of incorporation; shareholders who are denied transfers may claim appraisal rights. ${ }^{143}$

138 See Hup Choi, Woe-gook-in juk-dae-juk MEA sa-sbil-sang shil-byun ubryup-da [Actually Difficult for Foreign Hostile MEAs to Occur], CHOSUN ILBO, Feb. 9, 1998.

139 See $1995 \mathrm{KCC}$ art. 342-3. A similar five percent rule already exists under SEA art. 200-2.

140 See $1995 \mathrm{KCC}$ art. 335.

141 Explanatory Notes, supra note 83, at 84.

142 See id. at 85-86. Listed companies are excluded from this restriction under the SEA.

${ }^{143}$ In addition, if a company has decided to place this type of transfer restriction on a stock, convertible bond, or bond with warrant, then it must be included in the various documents related to such securities instruments. Such documents include the offer statements $(1995 \mathrm{KCC}$ arts. 302, 514, 516-4), the instrument certificates (1995 KCC arts. 356, 514, 516-4), and the securities instrument holder lists (1995 KCC arts. 514, 516-4). The information concerning the restriction must be registered (1995 KCC art. 317). 


\subsection{Corporate Spinoffs}

In conjunction with the new mergers regulations, for the first time corporations can spin off divisions into other corporations. An entire section devoted to corporate spinoffs was added to the 1998 amendments of the KCC under Section 11 immediately following the new section on mergers. ${ }^{144}$ These spinoff procedures offer another means to assist companies in their restructuring efforts. In particular, larger companies that needed to specialize their operations or that wanted to shed corporate divisions welcomed the new procedures. ${ }^{145}$

The new section on spinoffs broadly divides spinoffs into "Standard Spinoffs" and "Spinoff Mergers." 146 A Standard Spinoff involves a single company dividing into several different companies. Spinoff Mergers proceed one step further, occurring when a single company divides into several different companies and then one or more of these new companies simultaneously merge into other preexisting companies. Short-form spinoff mergers and small-scale spinoff mergers are also possible. ${ }^{147}$ In either case, the original company may or may not continue to exist, and only stock corporations can engage in spinoffs. ${ }^{148}$

Numerous restrictions have been established to protect interested parties such as shareholders and creditors during the spinoff process. First, shareholders must approve spinoffs with the same special majority vote required for mergers. ${ }^{49}$ Shareholders who object to Spinoff Mergers can furthermore request appraisal rights. ${ }^{150}$ While dissenting shareholders of Standard Spinoffs do not have appraisal rights, a provision provides that if the "burden of the shareholders" increases as a result of a Standard Spinoff or Spinoff Merger, then approval from all the shareholders is re-

144 See 1998 KCC sec. 11.

145 See Bok-ki Hong, Sang-bup-ae it-sub-sub Hwoe-sa-ui boon-bal-ae gwan-ban gyu-jung-ui do-ip-gum-to [Considering the Adoption of Regulations on Corporate Spinoffs in the Commercial Code], 17 COM. L. REV. 343 (1998); CHAN-SOO SHIN ET AL., KOREA LISTED CO. ASS'N, HWOE-SA-BOON-HAL-UI JAE-DO-WHAAE GWAN-HAN YON-GOO [RESEARCH STUDY ON THE REGULATION OF CORPORATE SPINOFFS] (Dec. 1995).

$1461998 \mathrm{KCC}$ art. 530-2.

147 See 1999 KCC art. 530-11.

148 See 1998 KCC art. 530-4.

149 See id. art. 530-3.

150 See id. arts. 530-11, 522-3. 
quired. ${ }^{151}$ Creditors also have considerable rights because they can block companies from engaging in Standard Spinoffs or Spinoff Mergers. ${ }^{152}$

Companies that remain in existence after a spinoff or companies established as a result of a spinoff are jointly and severally liable for all the debts of the company from which they originated. ${ }^{153}$ This obligation was created to deter firms from abusing the spinoff procedure. Otherwise, abusive dominant shareholders could, for instance, siphon assets to a spinoff company and leave the original company as a shell with all the liabilities.

In a Standard Spinoff, if shareholders of the original company approve of the spinoff by a special majority vote, the liabilities of the newly established spinoff company could be limited to the amount that the original firm invests into it. ${ }^{154}$ Similarly, for Spinoff Mergers, the liability could be limited to the amount that the original firm invests into the preexisting company that merges with the spinoff. In both Standard Spinoffs and Spinoff Mergers, if the original company continues to exist after the spinoff, then it will only be responsible for the liability not assumed by the new spinoff. Hanwha Living and Creative Corporation became the first spinoff of a listed company on July 1, 1999, when it divided into two companies. ${ }^{155}$

\subsection{The Expansion of Appraisal Rights}

Dissenting shareholders can now claim appraisal rights under a variety of new circumstances. ${ }^{156}$ The KCC provides that appraisal rights will be offered to shareholders in the following situations: (1) if a shareholder disagrees with a merger proposal or a significant sale or purchase of business operations; (2) if a

151 Id. art. 530-3.

152 See id. arts. 530-9, 530-11.

153 See id. art. 530-9.

154 See id.

155 See Yoon-jae Han, Gook-nae sang-jang-sa chut gi-up-boon-hal [First Corporate Spinoff of a Domestic Listed Company], CHOSUN ILBO, May 7, 1999; Young-sul Kwon, Han-wba-jong-bap-bwa-bak, 2 dae-sa-ro bool-li... ga-gongl won-ryo boo-moon [Hanwba Living and Creative Corporation Divided into Two Companies... Processing/Raw Materials Division], KOREA ECON. DAILY, May 3, 1999.

156 Appraisal rights used to be limited to publicly listed companies. See SEA art. 191. 
shareholder disagrees with a spinoff merger; or (3) if a shareholder's transfer of shares is denied. ${ }^{157}$

In the first two cases, where a shareholder disagrees with a merger or a significant sale or purchase of business operations, or with a spinoff merger, that shareholder can request appraisal rights. Shareholders must notify the company of their objection before the relevant shareholders' meeting and then request appraisal rights within twenty days after the shareholders' meeting. ${ }^{158}$ The company must then purchase the shareholder's stock within two months of this request.

In the case of restricted shares, shareholders must first notify the board of directors in writing of their intention to sell their shares to a certain person. ${ }^{159}$ The board of directors must notify the shareholders within one month after receiving this notice as to whether they approve the transfer. ${ }^{160}$ If the board rejects the transfer, then the shareholders may ask that the company designate an appropriate recipient to purchase the shares or may demand appraisal rights. ${ }^{161}$

In any case, when a company repurchases a shareholder's stock based on appraisal rights, the price is determined by consensus between the shareholder and the company. ${ }^{162}$ If they cannot agree to a price, an accounting expert or a court is supposed to determine the price. If more than thirty percent of the dissenting shareholders disagree with the price decided by the accounting expert, they can request that a court decide the appropriate price. ${ }^{163}$

After the price is determined and the stock is repurchased, the company must eventually dispose of the stock in due time. ${ }^{164}$ If

157 See $1995 \mathrm{KCC}$ arts. 335-2, 335-6 (transfer restrictions), art. 374-2 (significant sale or purchase of business operations), art. 522-3 (mergers), and art.53011 (spinoff mergers). Article 374-2 specifically applies to: (1) the sale of a company's entire business operations or a significant portion of it; (2) the execution, change, or termination of a leasing, management transfer, profit-loss sharing, or similar agreement involving a company's entire business operations; or (3) the purchase of another company's entire business operations.
158 See $1995 \mathrm{KCC}$ art. 374-2.
159 See id. art. 335-2, para. 1.
160 See id. para. 2.
161 See id. para. 4.
162 See 1995 KCC art. 335-5.
163 See id. art. 374-2, para. 4.
164 See id. art. 341-2, para. 3. 
several dissenting shareholders exist, one question that arises is whether the company must repurchase the various shares at the same price. The explanatory background of $1998 \mathrm{KCC}$, while not authoritative, suggests that the repurchase can be at the same price if the individual shareholders agree with the company. ${ }^{165}$

\subsection{Preferred Stock}

A notable goal of the new KCC is to revitalize the largely defunct preferred stock market in Korea. First issued in 1986 by the Oriental Brewery Company, preferred stock has been considered a failure in Korea. ${ }^{166}$ Prices of preferred stock have continued to hover at discounts of over fifty percent of the price of common stock, reflecting the lack of investor interest. ${ }^{167}$

The collapse of the price of preferred shares in Korea can be attributed to the fact that they have not offered any tangible benefits, especially when compared to common stock. Without exception, shares of preferred stock in Korea have been nonvoting and dividend-giving. ${ }^{168}$ The voting rights of preferred stock were usually cancelled in return for a "preferred" dividend. ${ }^{169}$ The problem was that the preferred dividends were too meager to offset the loss of the voting rights. With the increasing importance of the mergers and acquisitions market, preferred stock without voting rights in particular became increasingly unpopular. ${ }^{170}$

Preferred stock dividends were determined by merely adding one percent to the dividends given to common stock. ${ }^{171}$ This simplistic method of calculation was used because Article 344 of the previous Commercial Code only provided that dividends had

165 See Explanatory Notes, supra note 83, at 122.

166 See Chan-hyung Chung, Woo-sun-joo [Preferred Stock], GO-SHI-GYE, Mar. 1995, at 29.

167 The discount rate has been increasing recently with the advent of new preferred stock. See Analysis of Listing and Current Market Price of Preferred Stock, Public Disclosure Department, KSE Press Release, at 6-7 (July 30, 1999) (on file with author).

168 See Chan-hyung Chung, supra note 166. Preferred stock has also been nonparticating and noncumulative for dividend payments, and preferred stock that provides stock dividends or preferred distribution in the case of dissolution has not existed. See id.

$169 \mathrm{KCC}$ arts. 344, 370.

170 See Chan-hyung Chung, supra note 166.

171 See id. 
to be "preferred" to the amount of dividends awarded to common stock, without any further explanation as to what "preferred" meant. Dividends for common stock were already at a low level and typically awarded based on par value. ${ }^{172}$ Therefore, in determining the preferred dividend, one percent of the minimum 5000 won (U.S. \$4.17) par value of stock, or fifty won (U.S. $\$ 0.04$ ), was added to whatever dividends common stockholders received. ${ }^{173}$

To enhance the appeal of preferred stock, instead of paying a preferred stock dividend that merely fluctuated according to the dividends given to common stock, companies must now set in their articles of incorporation a minimum dividend that will be granted to preferred stockholders. ${ }^{174}$ This stipulation adds predictability and encourages higher dividends. As a result, most companies have fixed their minimum preferred stock dividends at nine percent of the 5000 won par value, which equals 450 won (U.S. \$0.38). ${ }^{175}$ Preferred stock that provides stock dividends or preferred distribution in the case of dissolution does not have to follow this minimum requirement. ${ }^{176}$ This new minimum requirement does not apply retroactively and only applies to preferred stock issued after October 1, 1996. ${ }^{177}$

Finally, to encourage the issuance of preferred stocks that award their dividends in the form of stock instead of cash, stock dividends can now be paid as any type of stock. ${ }^{178}$ This means

${ }^{172}$ See infra Section 3.8 for a further description of the generally low dividend policy.

${ }_{173}$ See Bup-jae byun-an [Current Legislative Issues], National Assembly Samoo-chuh, 95-15, at 8-9 (Oct. 24, 1995).

${ }_{174}$ See 1995 KCC art. 344. In February 1997, the Korea Green Cross Corporation was the first company to issue preferred stock with a minimum dividend. See Seung-il Hong, Choe-jub-bae-dang-ryul bo-jang joo-sbik deung-jang [Minimum Dividend Guaranteed Stock Appear], JoONGANG ILBO, Mar. 19, 1997.

175 Forty-five percent of preferred stocks listed under the new regulations have set their minimum dividend at nine percent. See Jeong Hwan Wui, Shinbyung woo-sun-joo bal-baeng gae-brooek sang-jang-bwoe-sa jun-chae-ui jul-ban [Half of Listed Companies Plan to Issue New Preferred Shares], MAEIL BUS. NEwS, Mar. 27, 1997.

176 See 1998 KCC art. 344.

177 Article 4 of the Addendum to the $1995 \mathrm{KCC}$ states that the provisions of Article 344 will only apply to preferred stocks issued after October 1, 1996, and will not apply retroactively to previously issued stock.

178 See $1995 \mathrm{KCC}$ art. 462-2, para. 1. 
preferred stockholders can conceivably receive stock dividends in either preferred stock or even common stock. ${ }^{179}$

\subsection{Dividends}

As mentioned earlier, a critical problem has been that dividends for common stock have been woefully inadequate. ${ }^{180}$ In 1997 , for instance, the average dividend yield in Korea was 3.22\%. From 1994 to 1998, companies averaged between 403 won (U.S. $\$ 0.36$ ) and 475 won (U.S. \$0.40) in dividends per share. ${ }^{181}$ Companies declared only the bare minimum dividend needed to meet the listing requirements or regulatory standards. ${ }^{182}$

Without sufficient dividend income, the investment goals for investors naturally shifted to short-term speculative trading instead of long-term capital gains. ${ }^{183}$ In a vicious circle, short-term investors would not persevere in monitoring or pressuring management for higher dividends, management would not feel obligated to declare more dividends than necessary, and, with low dividends, shareholders would lose their incentive for long-term investment.

The $1995 \mathrm{KCC}$ introduced a variety of incentives in an attempt to boost dividends, especially stock dividends. First, as

179 See Explanatory Notes, supra note 83, at 168-69. One question that remains is whether shareholders of previously issued preferred stock who receive newly issued stock should receive preferred stock according to the new rules that stipulate the minimum preferred dividend or according to the old rules that do not. According to an advisory opinion issued by the Korean Securities Supervisory Board, "old preferred stock" should continue to receive the same type of old preferred stock when receiving new issuances. See Moo-sang-jeung.ja woo-sun-joo-bae-jung 'non-lan' ['Dispute' over Distribution of Preferred Stock], KOREA ECON. DAILY, Sept. 26, 1996. In April 1998, the Stock Supervisory Board was merged into the Financial Supervisory Service. See Financial Supervisory Commission (visited Nov. 1, 1999) <http://www.fsc.go.kr > .

${ }_{180}$ See Jae-oh Yoon, $O l$ joo-chong bae-dang yang-geuk-hwa ddoo-ryut [Amount of Dividends Declared at This Year's Sharebolders' Meetings Clearly Diverge], MAEIL BUS. NEWS, Mar. 21, 1999.

181 See KOREA LISTED CO. ASS'N, 12 WOL GYUL-SAN SANG-JANG-HWOE-SA 1998 GYUL-SAN-SHIL-JUK MIT JAE-MOO-BOON-SUK [1998 ACCOUNT STATISTICS AND FINANCIAL ANALYSIS OF DECEMBER ACCOUNT LISTED COMPANIES] 16 (Apr. 1999) (on file with author).

182 To be listed on the First Section [Jae-1-bu] of the KSE, a company with a par value of 5000 won must issue at least a 300 won dividend. If a company does not issue dividends in two of the past three years, it will drop to the Second Section [Jae-2-bu]. See KSE, Yu-ga-jeung-kwon-sang-jang-gyu-jung [Regulations on Listing Securities] arts. 31.3, 32.5.

183 See KSE Press Release, supra note 37. 
mentioned previously, companies may now award stock dividends in any type of stock they wish. ${ }^{184}$ This additional potential enhances the options, and hence the attractiveness, of stocks. Second, a new calculation method has been developed for stock dividends. When the stock dividend to be awarded is less than one share and amounts only to fractional shares, companies may combine those fractional shares and either auction them or sell the stock on the stock market and then return the monetary proceeds as dividends to the shareholder. ${ }^{185}$ In the past, the KCC did not provide for methods of calculating fractional shares. ${ }^{186}$

Even more significantly, under the $1998 \mathrm{KCC}$, directors can declare cash dividends within a given year on a one-time basis. This option must be provided for in the company's articles of incorporation. ${ }^{187}$ Directors, however, must be careful when declaring interim dividends. If they declare interim dividends when the company lacks sufficient net assets on its balance sheet, the directors will be held jointly and severally liable for the difference. ${ }^{188}$ Directors can only avoid this type of liability if they demonstrate that they have met their duty of care. ${ }^{189}$ According to the Korea Stock Exchange, of the 516 listed companies with fiscal years ending in December 1998, forty-one have included a provision in their articles of incorporation that allows for interim dividends. ${ }^{190}$

Finally, companies must award dividends within one month after the shareholders' meeting at which the dividends were approved, unless shareholders have decided otherwise. ${ }^{191}$ The time period was shortened from two months because companies would consistently force shareholders to wait the full two-month period. ${ }^{192}$

$1841995 \mathrm{KCC}$ art. 462-2.

185 See id.

186 See Explanatory Notes, supra note 83, at 168-69.

187 See 1998 KCC arts. 462-3.

188 See id.

189 See id.

190 See Sung-won Lee, Dae-duk-san-up deung 22 sa aek-myun boon-bal: 12 wol bup-in jung-gwan byun-gyung [December Accounting Year Companies Make Changes in Articles of Incorporation: Daeduk Industries and 22 Other Companies Provide for Stock Splits], MAEIL BUS. NEWS, Mar. 30, 1999.

191 See $1998 \mathrm{KCC}$ art. 344 and $1998 \mathrm{KCC}$ art. 464-2. Interim dividends must be awarded one month after they are declared by the board of directors. See 1998 KCC art. 464-2.

192 See Explanatory Notes, supra note 83, at 173. 


\subsection{Capital Accumulation, Par Value, Stock Splits, and Stock Options}

Companies can raise capital more efficiently under the various revisions to the KCC. After incorporating, companies can set the amount of authorized stock according to their needs. In earlier KCC versions, firms could not increase their authorized stock more than four times the previous amount. ${ }^{193}$ Every time this relative limit was reached, companies had to call a shareholders' meeting to increase the authorized stock by amending the articles of incorporation. The revision seeks to make it less cumbersome for firms to attract capital. ${ }^{194}$

The restrictions governing the issuance of bonds have also been eased. Under the revised Article 470, companies can issue bonds up to four times the amount of assets provided on their balance sheet from the previous accounting year. ${ }^{195}$ Previously, companies were limited to twice the sum of their stated capital and reserves or, if total assets were less than this sum, twice their total assets. ${ }^{196}$

The $1995 \mathrm{KCC}$ allows holders of convertible bonds or bonds with warrants to convert their bonds even when the shareholder list has been closed for recording purposes prior to the shareholders' meeting. ${ }^{197}$ This makes bonds more attractive by giving bondholders added liquidity. Bonds converted to stock can not be used to participate at the shareholders' meeting for which the shareholder list has been closed. ${ }^{198}$

The $1998 \mathrm{KCC}$ aims to increase corporate liquidity and allow companies to raise capital more easily in other ways. First, the minimum par value of stocks has been dramatically lowered from 5000 won (U.S. $\$ 4.17$ ) to 100 won (U.S. \$0.08). ${ }^{199}$ While Korea still does not allow non-par value stock, lowering the minimum

${ }^{193}$ See $1995 \mathrm{KCC}$ art. 437, limiting the amount of authorized stock. This section was repealed in 1995.

194 See Explanatory Notes, supra note 83, at 156-57.

195 See $1995 \mathrm{KCC}$ art. 470.

196 See id.

197 See id. arts. 516, 516-10.

198 See id. arts. 350, 516, 516-9.

199 See $1998 \mathrm{KCC}$ art. 329. But see Ki-won Choi, supra note 35 (arguing that the par value should not have been lowered below the 1962 requirement of 500 won (U.S. \$0.41)). 
par value helps entities, such as venture companies, to raise capital more effectively.

Korean corporations can now execute stock splits. ${ }^{200}$ Stock splits require a special majority shareholder vote and must follow the same procedures used for stock mergers. ${ }^{201}$ In conjunction with the lower minimum par value, stock splits have become easier to achieve. They enhance liquidity and allow stock prices to be adjusted to make mergers and acquisitions more attractive. Stock splits are increasingly gaining in popularity: of the 516 listed companies with fiscal years ending in December 1998, twenty-two companies decided to carry out stock splits, resulting in lower par values. ${ }^{202}$

Finally, unlisted companies can issue stock options in the same manner as listed companies. ${ }^{203}$ Companies can issue stock options at a predetermined rate to directors, auditors and employees after a special majority vote. Shareholders who have more than ten percent of the issued shares, those who have "actual influence" in the election or termination of directors or auditors, or direct relatives of any of these persons, are specifically ineligible to receive stock options. The total amount of stock options cannot exceed ten percent of the total number of issued shares. Persons with stock options can exercise them after holding their position for at least two years after the special majority shareholder vote to issue the stock options. Stock options are not transferable, but may be inherited.

\section{THE CHANGING CORPORATE LANDSCAPE}

The recent amendments to the $\mathrm{KCC}$ have helped reshape Korea's corporate environment. The most visible developments affect corporate governance. A host of practically defunct, but critical, legal provisions in the KCC were used for the first time. For example, the lower shareholder holding requirements have helped once passive shareholders, particularly those with nonprincipal interests, to assert their rights in an unprecedented fash-

200 See 1998 KCC art. 329-2.

201 See id. arts. 440 to 444.

202 See Bong-kwon Park, Aek-myon-boon-bal gi-up si-jang-soo-ik-ryul 3 bae isang cho-gwa-soo-ik-ryul ol-lyub [Companies that Split Stock Had Profit Yields Three Times Greater Than that of Market Yields], MAEIL BUS. NEWS, Mar. 24, 1999.

203 See $1999 \mathrm{KCC}$ arts. 340-2 to 340-5, 341-2; SEA art. 189-4. 
ion. ${ }^{204}$ Shareholders have brought the first-ever derivative actions against directors and have even made challenges for corporate control. ${ }^{205}$

Although not yet numerous, hostile takeover bids have been attempted and target companies have learned to employ various types of defensive tactics. ${ }^{206}$ The first successful hostile takeover under the SEA is considered to be Savoy Hotel's acquisition of Shinsung Trading. ${ }^{207}$

A confluence of other factors has increased the effectiveness of the changes to the KCC. Upon realizing that they have rights, shareholders are becoming more active participants in corporate affairs. ${ }^{208}$ Investors are challenging management regarding decisions, performance, and misconduct. ${ }^{209}$ Foreign investors are also

204 See Mark L. Clifford, The Stars of Asia, BUS. WK. INT'L EDITION, June 29, 1998, at 70; Jon E. Hilsenrath \& Namju Cho, Shareholders Begin to Show Muscle in Korea, ASIAN WALL ST. J., Mar. 20, 1998, at 1; Moon Ihlwan, The Shareholder Revolt Comes to Korea, BUS. WK., Feb. 23, 1998, at 52; Michael Lewis, The World's Biggest Going-out-of-Business Sale, N.Y. TIMES MAG., May 31, 1998, at 34, 53; Sandra Sugawara, South Korea Takes on Family Business Groups, WASH. POST., Mar. 11, 1999, at E2; Jennifer Veale, This Time Around, Goliath May Strike Back, BUS. WK. INT'L EDITION, Mar. 29, 1999, at 26; George Wehrfritz, A Revolution in the Boardrooms, NEwSWEEK, Nov. 9, 1998, at 14-17. The minority shareholder movement in Korea has been largely spearheaded by the Participatory Economic Committee ( ${ }^{\mathrm{PEC}}$ ) ) of the People's Solidarity for Participatory Democracy ("PSPD"), a public interest group. See Participatory Economic Committee (visited Mar. 23, 2000) < http://www. pspd.org/pec $>$.

${ }^{205}$ See infra notes 256-60 and accompanying text for a discussion of the first derivative action.

206 Some recent target companies where management control was challenged include Caproraktam, Hangdo Merchant Bank, Ulsan Merchant Bank and Midopa. See Byung-gi Hong, Caproraktam joo-chong-sub ddo kyuk-dol [Another Collision at Caproraktam's Shareholders' Meeting], JoONGANG ILBO, Feb. 28, 1996; Byung-il Yeh, Hang-do-jong-geum ji-joo-bwoe-sa gong-bang [Hangdo Merchant Bank Having Holding Company Debate], CHOSUN ILBO, Jan. 4, 1997; Byung-il Yeh, Mi-do-pa MEA boon-jaeng bon-gyuk-bwa [Midopa MEA Dispute Begins in Earmest], CHOSUN IIBO, Jan. 25, 1997; Byung-il Yeh, Ul-san-jong. geum-do MEA bi-sang [Ulsan Merchant Bank also Faces an MEA Emergency], CHOSUN Ilbo, Dec. 11, 1996.

207 See Hun-soo Kim, Shin-sung-moo-yuk MEA ma-moo-ri [MEA of Shinsung Trading Completed], MAEIL BUS. NEWS, Nov. 27, 1997; Byung-il Yeh, Savoy Hotel Shin-sung-moo-yok in-soo [Savoy Hotel Acquires Shinsung Trading], CHOSUN IIBO, Aug. 1, 1997.

208 See Hong-ryul Chun, supra note 110, at 77.

209 See Hae-won Choi, In Seoul: South Korean Companies Bend to Assuage Activists, ASIAN WALL ST. J., Mar. 24, 1999, at 13; Sung-il Hong,Joo-joo ja-bonjoo-ui shi-bum moo-dae [Shareholder Capitalism Test Case], JOONGANG ILBO, 
assuming a more demanding presence, acquiring companies, and questioning management. ${ }^{210}$ The urgency of the financial crisis forced companies to place an emphasis on shareholder value in order to attract large-scale capital infusions and accept debt for equity swaps. This led to a relinquishment or co-sharing of management control in many cases. Several notable examples will be examined to illustrate how the new corporate regulations and the new environment have affected corporate Korea.

\subsection{The Kickoff: Daehan Pulp and Oriental Brewery}

In October 1996, the first signs of a changing corporate environment emerged. On October 22, 1996, eighteen minority shareholders of Daehan Pulp requested the convening of a special shareholders' meeting to terminate the chairman of the board of directors. ${ }^{211}$ 'This request for a special shareholders' meeting was considered the first case in which shareholders formally exercised their shareholder rights since the enactment of the KCC in 1962. ${ }^{212}$ Shareholders sought to hold Daehan Pulp's management accountable for losses they suffered when Daehan Pulp initially disclosed and then withdrew its intentions to enter the telecommunications sector. ${ }^{213}$

Management, in contrast, claimed they were victims of stock manipulation and that the shareholder action itself was being led

Feb. 16, 1998, at 27; Charles Lee, Fairer Shares, FAR E. ECON. REV., Apr. 1, 1999 , at 56 (stating that "the chaebols have woken up to the potency of shareholder activism and have showed an uncharacteristic deference to it" and that "Jang and his cohorts at the PSPD have unleashed seismic changes in Korean corporate culture"); Jung-Jae Lee, So-aek-joo-joo gwon-li-chat-gi gae-in-deul mokso-ri kub-jyub [As Minority Sharebolders Claim Rights, Voices of Individuals Get Larger], JOONGANG IIBO, Apr. 1, 1998.

210 See discussion infra Section 4.4.

211 See Young-soo Kim, Daeban Pulp/Too-ja-ja son-sbil-ip-bin dae-pyo-i-sa twoe-jin-yo-goo [Daehan Pulp: Demanding the Removal of the Representative Director that Caused Losses to Investors], CHOSUN ILBO, Nov. 7, 1996, at 13; Sanghoon Song, So-soo-joo-joo joo-chong-so-jip yo-goo non-lan/Daeban Pulp [Debate Over Minority Sharebolders' Request to Convene a Sharebolders' Meeting/Daeban Pulp], JOONGANG ILBO, Nov. 7, 1996, at 31 [hereinafter Sang-hoon Song, Debate over Request].

212 See Dong-han Lee, Jip-joong boon-suk: So-aek-joo-joo woon-dong [Special Focus: Minority Sharebolder Movement], CHOSUN ILBO, Apr. 2, 1999, at 12; Sang-hoon Song, Debate Over Request, supra note 211.

213 See Sang-hoon Song, Debate over Request, supra note 211. 
by manipulators. ${ }^{214}$ Eventually, before a court decision was reached, this dispute was settled when the shareholders dropped their request and reached an agreement with Daehan Pulp's management. ${ }^{215}$ This case nevertheless had significant precedential value and opened a new dimension in relations between shareholders and management.

Shortly after the Daehan Pulp case, shareholders of the Oriental Brewery ("OB") company followed suit and in November 1996, exercised their shareholder rights. The $O B$ case arose when a subsidiary of $O B$ sought to expand its market presence in certain regional markets and sell soju, a Korean liquor, directly in competition with several local manufacturers. ${ }^{216}$

In response to this challenge, three local soju companies joined forces and began acquiring shares in $\mathrm{OB}$ as a countermeasure. After acquiring a fifteen percent stake in $O B$, they then requested the first-ever inspection of a company's corporate books. ${ }^{21}$ This type of shareholder strategy was one of the first of its kind. Given generally opaque Korean accounting practices, a request for an inspection would be a considerable challenge to almost any company because it could expose sensitive financial information and accounting irregularities. $O B$ countered that this inspection request was an abuse of shareholder rights to intimidate it into withdrawing from the regional soju markets. ${ }^{218}$

On January 24, 1997; the Seoul District Court issued an opinion approving the petition to inspect OB's books. ${ }^{219}$ This deci-

${ }^{214}$ See Young-soo Kim, "Dae-ban-pulp" bon-gyuk-dae-gyul dol-ip [Serious Challenge for Daeban Pulp Begins], CHOSUN ILBO, Nov. 8, 1996.

215 See Jin-woo Lee, Daeban Pulp so-aek-joo-joo "joo-chong-so" chui-ba [Daehan Pulp Small Sharebolders Withdraw Sharebolders' Meeting Action], MAEIL BUS. NEWS, Jan. 8, 1997, at 21.

216 See Sang-hoon Song, 'Gyung-wol ji-bang-jin-chool' bup-jung-ssa-woom [Legal Battle over 'Gyungwol's Entry into Regional Market'], JOONGANG ILBO, Nov. 19, 1996 [hereinafter Sang-hoon Song, Legal Battle].

217 For another recent example of a court finding that shareholders have a right to inspect a company's records provided they have a legitimate reason and meet the relevant holding requirement, see Judgment Mar. 11, 1998, Seoul Ji-bang-bup-won [District Court], Jae $19 \mathrm{Min}-\mathrm{sa}-\mathrm{bu}$ [19th Civil Division], 97 Kahap 68790.

218 See Sang-hoon Song, Legal Battle, supra note 216.

${ }^{219}$ See Sang-ryul Lee, Ji-bang-so-joo 3 gae-sa-ae $O B$ jang-boo yol-lam bub-yong [Three Local Soju Companies Allowed to Inspect OB's Books], JOONGANG ILBO, Jan. 23, 1997, at 4; Myung-soo Suh, So-soo-joo-joo-deul kyung-young gam-shi bwal-bal yei-go [Many Predict Minority Shareholders Will Actively Monitor Corporate Management], JOONGANG ILBO, Jan. 24, 1997, at 5; Jung-hwan Wui, So-joo- 
sion became the first case where a court formally recognized the exercise of a shareholder's rights under the KCC. ${ }^{220}$ The Court held that the shareholders had met the necessary holding requirement and were therefore entitled to exercise their legally guaranteed rights. Ultimately, the inspection was not carried out because the parties reached a compromise. Nevertheless, both the Daehan Pulp and OB cases were significant because they awakened shareholders and corporate Korea to the potential impact and importance of shareholder rights. ${ }^{221}$

\subsection{Challenges to Corporate Control: Hanwha Merchant Bank and Midopa Department Store}

In another notable episode in Korean corporate history, a longstanding minority investor attempted to assume control of a financial institution. This challenge was significant not only as the first major takeover attempt in Korea, but furthermore because the target, Hanwha Merchant Bank ("HMB"), was a subsidiary of a chaebol conglomerate, the Hanwha Group. ${ }^{222}$ Ui-song Park, the second largest shareholder, amassed a near dominant forty percent of the outstanding shares of $\mathrm{HMB}$, primarily through his company, Woopoong Mutual Savings and Finance, and another friendly partner. ${ }^{223}$ On December 6, 1996, Park an-

joo, Sang-jang-sa jang-boo-yeol-lam cbut bub-yong [Minority Sharebolders Allowed for the First Time to Inspect Corporate Books of a Listed Company], MAEIL BUS. NEWS, Jan. 22, 1997.

${ }^{220}$ See Jung-hwan Wui, supra note 219. In a subsequent opinion, the Seoul High Court reversed a lower court decision and found that the company has the burden to prove that a shareholder's request is unreasonable. See Myungjin Lee, [Bup-won] Gyung-young jal-mot ib-jeung mot-bae-do ju-ju jang-bu yol-lamgyon bo-jang, [Courts: Sharebolder's Inspection Rights Guaranteed Even if Mismangement Not Proven], CHOSUN ILBO, Dec. 25, 1998. Gyo-chang Kim suggested earlier that companies should have the burden of proof. See Gyo-chang $\mathrm{Kim}$, Sang-bup-joong bwoe-sa-pyun-ui gae-jung-ui-gyun [Opinion on the Amendment of the Stock Corporation Section of the Korean Commercial Code], L. TIMES (Seoul), Mar. 12, 1998, at 14.

${ }^{221}$ See Joo-byung Park, So-soo-joo-joo-deul gwon-li-baeng-sa neul-ub-nan-da [More Cases of Shareholders Exercising Their Rights], KOREA ECON. DAILY, Jan. 3, 1997.

${ }^{222}$ See Sang-hoon Song \& Shin-sung Shik, Dae-gi-up sang-dae gook-nae chut $M E A$ [First Domestic $M E A$ of a Large Conglomerate], JOONGANG ILBO, Dec. 7, 1996, at 1; Woopoong Mutual Secures 40\% Stake in Unit of Hanwha, ASIAN WALL ST. J., Dec. 9, 1996, at 3.

223 See Sang-hoon Song \& Shin-sung Shik, supra note 222; Woopoong Mutual Secures 40\% Stake in Unit of Hanwha, supra note 222. 
nounced that he had filed a petition with the Seoul District Court requesting specific performance to convene a special shareholders' meeting so that he could claim control of the management of the company. ${ }^{224}$

While corporate Korea looked on in great anticipation, on January 7, 1997, the board of HMB employed a surprising takeover defense. They nullified Park's efforts through a private placement of forty billion won (U.S. $\$ 33.3$ million) in convertible bonds ("CB") to three friendly partners. ${ }^{225}$ The three promanagement parties that acquired the convertible bonds then immediately converted the bonds into stock. These white squires gained seventeen percent of the total voting shares of HMB and helped management to successfully dilute shares favorable to Park. ${ }^{226}$

Park, in turn, challenged management's takeover defense. He attempted to enjoin the voting rights of the management-friendly shareholders who purchased the convertible bonds. ${ }^{227} \mathrm{He}$ claimed that the issuance of the convertible bonds by HMB's management to protect their control violated their fiduciary duty under the KCC. ${ }^{228}$ Although sympathetic to Park's claim, the Seoul District Court ultimately rejected Park's arguments. ${ }^{22}$ The District Court stated that, despite the interests of shareholders, the voting rights stemming from the convertible bonds could not be cancelled at that stage because the instruments had been already is-

224 See Sang-hoon Song \& Shin-sung Shik, supra note 222.

225 The three friendly partners were Samshin-Allstate, HiFive, and Donghung Electric. See Myung-soo Suh, Han-wba-jong-geum sa-mo-sa-cbae junkyuk bal-baeng [Hanwha Merchant Bank Issues Private Placement of CBs], JOONGANG ILBO, Jan. 9, 1997, at 3.

226 See Myung-soo Suh, Han-wha-jong-geum sa-mo CB chut joo-shik jun-bwan [Hanwha Merchant Bank Privately Placed CB Converted into Stock], JoONGANG ILBO, Jan. 12, 1997, at 1.

227 See KCC art. 424.

228 See Byung-il Yeh, Han-wba-jong-geum: Gyung-young-gwon byang-bang bup-won-su pan-ga-reum-nal-dut [Hanwba Merchant Bank: Appears the Future of Management Control Will Be Decided by the Courts], CHOSUN ILBO, Jan. 9, 1997. Fourteen minority shareholders also brought suit against the issuance of the convertible bonds. Han-wba-jong-geum so-aek-joo-joo so-song [Minority Sharebolders of Hanwha Merchant Sue], JOONGANG ILBO, Jan. 11, 1997, at 1.

${ }^{229}$ See Judgment of Feb. 6, 1997, Seoul Chi-bang-bup-won [District Court], Jae 50 Min-sa-bu [50th Civil Division], $97 \mathrm{Kkahap} 118$; see also Byung-il Yeh, Han-wha jong-geum in-soo shi-do moo-san [Hanwba Merchant Bank Takeover Attempt Thwarted], CHOSUN ILBO, Feb. 7, 1997, at 9. 
sued and converted into stock. ${ }^{230}$ The court was concerned that denying the voting rights of the stock would undermine the "safety of the market." "Wi1 With their additional voting power secured, Hanwha narrowly defeated Park's takeover attempts at the special shareholders' meeting held on February 13, 1997.32

This district court ruling was problematic for a number of reasons. The converted stocks in question had yet to be listed; furthermore, the original purchasers still held the converted stocks. Therefore, it is not clear why there would have been any serious market disruption if their voting rights were denied. On appeal, Park requested an injunction to cancel the convertible bonds. ${ }^{233}$ The Seoul High Court, in turn, agreed that the issuance of the convertible bonds should be cancelled because they infringed on the rights of shareholders. ${ }^{234}$ The court cited that the primary purpose of the issuance of the bonds was to defend management's control. ${ }^{235}$ However, the High Court ultimately deferred judgment on whether the voting rights should be denied.

During this dramatic series of events, several rarely-employed provisions of the KCC were once again used. Park's request for a special shareholders' meeting, for instance, was considered to be only the second case, after Daehan Pulp, of a shareholder in Korea bringing such a request. ${ }^{236} \mathrm{Next}$, as with the $O B$ case, Park asked for an inspection of the corporate books. ${ }^{237}$ Third, the special shareholders' meeting that was held produced the first-ever

${ }^{230}$ See Judgment of Feb. 6, 1997, supra note 229.

231 Id.

232 See Sang-hoon Song, Han-wba "Jong-geum gyung-young-gwon" bang-ub [Hanwha Defends Challenge Against "Merchant Bank Management"], JOONGANG ILBO, Feb. 14, 1997, at 26.

233 See Judgment of May 13, 1997, Seoul Go-deung-bup-won [High Court], $97 \mathrm{Ra}$ 36; Judgment of Feb. 6, 1997, Jae 50 Min-sa-bu [50th Civil Division], 97 Kahap 118.

234 See id.

235 See id.

236 KCC art. 366.

237 See Sang-hoon Song \& Shin-sung Shik, supra note 222. 
proxy fight in Korea. ${ }^{238}$ This battle for control eventually became moot when $\mathrm{HMB}$ was declared insolvent. ${ }^{239}$

At about the same time as the HMB case, another major hostile takeover attempt occurred. On January 23, 1997, Dongbang Peregrine Securities announced that it wished to elect a new management for Midopa Department Store. ${ }^{240}$ Midopa was the flagship company of the thirty-fourth largest conglomerate in Korea, the Dainong Group. Dongbang Peregrine claimed that Midopa could be managed more effectively. ${ }^{241}$ Not only did this case involve another challenge against a chaebol company, but it was also a hostile takeover attempt that was launched by an entirely outside conglomerate.

Following the Hanwha experience and other recent examples, several provisions of the KCC were utilized again. First, Dongbang Peregrine declared its interest in inspecting Midopa's corpo-

238 See KCC art. 368; see also Byung-il Yeh, Hanwha-Park Ui-song: Hanwha-jong-geum wui-im-jang jeng-tal-jun, CHOSUN IIBO, Jan. 30, 1999. The first proxy solicitation initiated by a foreign shareholder occurred in March 1998 against SK Telecom. See infra notes 268-70 and accompany text for a detailed discussion of the SK Telecom proxy solicitation.

${ }^{239}$ See In-soo Kim, Woe-bwan-wui-gi joo-bum boo-shil-jong-geum-sa pa-sanchub-ri-do him-deul-ub [It's Also Difficult to Liquidate the Main Culprits of the Foreign Currency Crisis, the Improperly Run Merchant Banks], MAEIL BUS. NEWS, Oct. 22, 1998.

${ }^{240}$ See Byung-il Yeh, Mi-do-pa-joo-chong-sub ui-gyul-gwon baeng-sa [Exercising Shareholder Rights at the Midopa Sharebolders' Meeting], CHOSUN ILBO, Jan. 24, 1997.

${ }^{241}$ See id. Some reports claimed that Dongbang Peregrine was merely greenmailing Midopa on behalf of unknown foreign investors that reportedly held up to 20\% of Midopa's shares. See Young-shin Yoon, Hongkong Money: gook-nae joong-gyun-gi-up-joo jip-joong-mae-jip [Hong Kong Money: Concentrate Purchases of Stock of Middle Size Domestic Companies], CHOSUN ILBO, Feb. 7, 1997. The Securities Supervisory Board censured Dongbang-Peregrine for "illegal parking," (i.e., using a third party to acquire Midopa shares to avoid disclosure requirements), which was considered one of the first such cases ever. See Byung-1l Yeh, Bool-bup 'Parking' baeng-wui gi-seung [Illegal 'Parking' Practice Flourisbes], CHOSUN ILBO, July 9, 1997, at 12. Ultimately, Shindongbang, the joint venture partner of Peregrine that established Dongbang-Peregrine, later emerged as the real suitor seeking to take control of Midopa. See Byung-il Yeh, Shin-dong-bang Group: Mi-do-pa-joo mae-jip bwak-in [Shindongbang Group Confirms It Purchased Midopa Shares], CHOSUN ILBO, Mar. 5, 1997. See generally Seong C. Gweon, Play a Fair Game, Please, Korea HERALD, Mar. 12, 1997 (discussing the various financial regulations breached during the deal). 
rate books. ${ }^{242}$ Second, Shindongbang requested a special shareholders' meeting to elect new management. ${ }^{243}$

Midopa, in the meantime, followed HMB's strategy and issued a private placement of fifty billion won (U.S. $\$ 41.7$ million) worth of convertible bonds and, later, bonds with warrants. ${ }^{244}$ In this case, however, the Seoul District Court issued an injunction preventing Midopa from offering the convertible bonds or the bonds with warrants. ${ }^{245}$ The court found that the Midopa case differed from the Hanwha case because the injunction was requested before the bonds were issued and therefore a compelling public interest to protect the market did not exist. ${ }^{246}$

While Midopa tried to defend itself, another unheard of event occurred. One of Korea's three major investment trusts, Korea Investment Trust Company ("KITC"), initially opposed Midopa's attempt to issue the privately placed convertible bonds. KITC threatened that if Midopa issued the convertible bonds, in the "interest of minority shareholders and institutional shareholders," it would transfer its $7.7 \%$ share of Midopa stock to the party threatening the takeover. ${ }^{247}$ This marked a rare occurrence of an institutional investor publicly acting on behalf of the interests of its customers against actions taken by a company in which

${ }^{242}$ See Byung-il Yeh, "Mi-do-pa MEA pa-moon" joo-yok Paul Pbeby, jeung. gwon-jun-moon-ga-in-ga gyo-ran-ja-in-ga [Paul Pheby, the Main Actor of the "Repercussions of the Midopa MEA": Is He a Securities Specialist or a Market Disrupter], CHOSUN ILBO, Feb. 2, 1997.

${ }^{243}$ See Myung-soo Suh, Shin-dong-bang, Mi-do-pa-jang-ak jun-myun-gong-sae [Shindongbang, Frontal Offense to Take Control of Midopa], JOONGANG IIBO, Mar. 13, 1997. Although Midopa was able to withstand Shindongbang's challenge, in the end the entire Dainong Group and Midopa collapsed largely from the strain of defending the takeover. See Midopa Is Declared Bankrupt After Loan Woes, ASIAN WALL ST. J., Mar. 19, 1998, at 4.

244 Midopa also attempted to issue privately placed bonds with warrants. See Sang-hoon Song, Midopa BW bal-haeng gye-bwoek moo-san [Midopa's Plans to Issue BWs Stopped], JOONGANG ILBO, Feb. 28, 1997, at 8.

${ }^{245}$ The bonds would have been convertible before July 1, 1997. Judgment of Feb. 27, 1997, Seoul Ji-bang-bup-won [District Court], Jae 50 Min-sa-bu [50th Civil Division], 97 Kkahap 481. See Midopa Issues Bonds in Defensive Move, ASIAN WALI ST. J., Mar. 10, 1997, at 13 [hereinafter Defensive Move].

${ }^{246}$ Midopa later issued the bonds by changing the terms so that shares could be converted after July 1,1997, which would prevent them from being exercised at Midopa's annual shareholders' meeting in the fall. See Defensive Move, supra note 245.

${ }^{247}$ Mi-do-pa sa-mo CB bal-haeng ban-dae [Korea Investment Trust Objects to Midopa's Private Placement of CBs], CHOSUN ILBO, Jan. 31, 1997, at 1. 
they invested. In Korea, fund managers have tended to be passive and restrained. 248

Overall, several aspects of the HMB and Midopa cases are noteworthy. First, both cases demonstrated the enormous possibilities and the importance of shareholder rights. ${ }^{249}$ Second, they exposed the vulnerability of corporate control in Korean companies and demonstrated that even firms within chaebol conglomerates were not immune from challenges. Although companies can no longer issue private placements of bond offerings when facing hostile threats, the defensive responses by Midopa, and previously Hanwha, demonstrated the seriousness and urgency of their concerns. ${ }^{250}$ In the aftermath of the Hanwha and Midopa incidents, sixty-eight companies issued such private placements of convertible bonds primarily to secure management control. ${ }^{251}$ Although

248 See Byung-il Yeh, Gi-grwan-too-ja-ga-deul byun-sbin [Institutional Investors Are Changing], CHOSUN ILBO, Feb. 1, 1997, at 8.

${ }^{249}$ At one point there was speculation that the Shindongbang Group might try to take over not only Midopa, but also the entire Dainong Group. See Sang-hoon Song, Dai-nong num-bo-gi... group MEA ga-neung-sung [Interest in Dainong... Possibility of a Group MEA], JOONGANG ILBO, Mar. 6, 1997. Another bizarre event indicative of the collusive ties between many chaebol conglomerates was that the Federation of Korean Industries, composed of the nation's top chaebols, declared that it would join forces together to defend the takeover of Midopa. This hasty solution was quickly withdrawn after pressure from the Korean Fair Trade Commission. See Namju Cho, Korea Takes New Step, supra note 48; In-bae Seung, Jae-gye "Juk-dae-juk $M E A$ gong-dong-dae-eung [Industry Declares that It Will "Jointly Defend Hostile Takeovers"], CHOSUN ILBO, Mar. 12, 1997, at 11; Kyung-min Chung, $M E A$ gong-dong-dae eung motban-da [Joint Defense of MEA Cannot Occur], JOONGANG ILBO, Mar. 14, 1997; In-bae Seung, Jae-gye "Tuk-dae-juk MEA gong-dong-dae-eung [Industry Declares that It Will "Jointly Defend Hostile Takeovers"].

250 See SEA art. 24, SEA Implementing Decree arts. 10, 12-5; see also Sangryul Lee, Gyung-young-gwon boon-jaeng-joong-in gi-up: sa-mo-jun-bwan-sa-chae bal-baeng-geum-ji 1 nyun-gan joo-shik-jun-bwan-do bool-bub [Companies Whose Management Control is in Dispute Probibited from Private Placement of Convertible Bonds and Bonds Cannot Be Converted into Stock for One Year], JOONGANG ILBO, Mar. 20, 1997.

251 See Tae-ung Chung, Sa-mo-jun-bwan-sa-chae bup-won-pan-kyul-ro MEA tae-ma ban-kam dwoel-deut [The Judicial Decision on Privately Placed Convertible Bonds Likely to Thwart MEA], KOREA ECON. DAII Y, Feb. 9, 1997, at 4; Korean Firms Issued \$1.36 Billion of Convertible Bonds in Quarter, ASIAN WALL ST. J, Apr. 3, 1997, at 20; Myung-soo Suh, Sa-mo-sa-chae joo-sbik keun pok ba-rak [Privately Placed CB Stocks Drop by Big Margins], JOONGANG ILBO, Feb. 7, 1997, at 3; see also Kil-yong Ahn, Sa-mo-sa-chae-ui moon-jae-jum gum-to mit dae-chek [Reviewing the Problems and Solutions for Private Placement Bonds], 37 SANG-JANGHYUP 119, 130 (1998) (describing how companies have used private placement of bonds to protect their management control in recent years). 
unsuccessful, these two cases were nevertheless the first serious hostile takeover attempts to occur in Korean corporate history.

\subsection{Seeking Management Accountability: Korea First Bank}

In terms of capturing the attention of Korean management, perhaps no event had a greater impact than the case of Korea First Bank ("KFB"), once one of Korea's premier banks. As the primary lending bank to a string of failed chaebols that collapsed in spectacular fashion, including the Hanbo Group, Kia Group, and Sammi Group, the government was forced to nationalize KFB in February 1998. ${ }^{252}$ KFB's troubles exemplified the ineffective corporate governance of financial intermediaries in Korea. Unchecked by shareholders, Korean banks were always highly susceptible to outside pressures.

First, KFB management faced tough questions from organized shareholders regarding their roles in the Hanbo Group scandal during the annual shareholders' meeting held in March 1997. This marked one of the first times that minority shareholders systematically and vocally challenged a major corporation's management at a shareholders' meeting. ${ }^{253}$ Their most fundamental rights of participation and voting were exercised. KFB management crudely tried to prevent shareholders from participating in the annual shareholders' meeting and then managed to summarily steamroll through various management proposals. However, minority shareholders later brought legal actions challenging the procedural breaches, irregularities, and validity of the resolutions made at this annual shareholders' meeting.

Two significant court decisions emerged from the events surrounding the failure of KFB. First, in a critical case, the Seoul District Court held that the resolutions of the annual sharehold-

252 See Michael Schuman, Korea Watches, Waits as Sammi Group Seeks Court Protection from Creditors, ASIAN WALL ST. J., Mar. 20, 1997, at 1.

${ }^{253}$ See Myung-jae Lee, Jae-il-eun joo-chong . . sung-nan so-aek-joo-joo-deul [KFB Shareholders' Meeting . . Angry Minority Shareholders], DONGA ILBO (Seoul), Mar. 8, 1997, at 37. Minority shareholders also raised serious challenges at KFB's 1998 and 1999 shareholders' meetings. See Tae-ung Chung \& Hong-yul Kim, Eun-heng sal-ja-go so-aek-joo-joo da jook-ib-na [Sacrificing All the Minority Sharebolders to Save the Bank], KOREA ECON. DAILY, Mar. 3, 1999; Hong-ki Kim \& Byung-il Yeh, Boo-sbil-chek-im cbu-goong-jung-chek-bi-pan 'botmool': eun-baeng-joo-chong 'dae-byun-bwa' ['Flood' of Questioning Responsibility for Mismanagement and Criticizing Policies: 'Great Change' in Bank Sharebolders' Meetings], CHOSUN ILBO, Feb. 28, 1998, at 9. 
ers' meeting should be cancelled because of the various procedural errors that occurred. They specifically cited the failure to give objecting shareholders a chance to express their views. ${ }^{254}$ The Court stated that its decision disregarded how companies may have conducted shareholders' meetings in the past. For the first time, a court accepted a minority shareholder's petition to cancel resolutions that were passed at a shareholders' meeting. ${ }^{255}$

Next, furious KFB stockholders initiated the first-ever shareholder derivative action in Korea. ${ }^{256}$ Shareholders claimed that over 1.1 trillion won (U.S. \$916.6 million) in bad loans to the Hanbo Group in particular led to over 270 billion won (U.S. \$225 million) in losses to the bank. ${ }^{257} \mathrm{KFB}$ management allegedly received bribes in return for these loans. In a historic decision, the Seoul District Court not only found KFB directors responsible for mismanagement and misconduct, but awarded a record forty billion won (U.S. $\$ 33.3$ million) judgment against four former $\mathrm{KFB}$ directors on behalf of the shareholders. ${ }^{258}$

254 See Judgment of Dec. 12, 1997, Seoul Chi-bang-bup-won [District Court], Jae 22 Hap-ui-min-sa-bu [22nd Civil Division], 97 Kahap 32890; seealso Chang-won Lee \& Sung-soo Bang, So-aek-joo-joo moo-shi-ban joo-chong-gyul-uineun moo-byo [Sharebolders' Meeting Resolutions that Disregarded Minority Shareholders Is Void], CHOSUN ILBO, Dec. 13, 1997, at 27. Other recent examples of successful actions against shareholders' meetings include Judgment of Feb. 2, 1999, Seoul Chi-bang-bup-won [District Court], Jae 14 Hap-ui-min-sabu [14th Civil Division], 98 Kahap 24407.

${ }^{255}$ See Lee \& Bang, supra note 254. On appeal, however, the Seoul High Court reversed the cancellation of the resolutions of the shareholders' meeting primarily because of the overwhelming consequences to shareholders and the Korean economy that would have resulted. See Judgment of Aug. 25, 1998, Seoul Go-deung-bup-won [High Court], Jae $9 \mathrm{Min}-\mathrm{sa}-\mathrm{boo}, 98 \mathrm{Na} 5267$. The High Court did emphasize that otherwise it would be proper to cancel the resolutions of the meeting.

${ }^{256}$ See Dae-yon Kim, Joo-joo-dae-pyo-so-song-gwa gyong-young-pan-dan-uiwon-chik [Shareholder Derivative Actions and the Business Judgment Rule], 17 COM. L. REV. 111 (1999); see also Hong-yul Kim, Jae-il-eun-baeng so-aek-joo-joodeul i-sa-jin-sang-dae son-shil-bo-jun cbung-goo so-song [Minority Sharebolders of KFB Bring Suit Against Directors], CHOSUN ILBO, Apr. 11, 1997; Jin-woo Lee, Gook-nae choi-cho joo-joo dae-pyo so-song ... cham-yub-yon-dae, jae-il-eun-baeng goo-gyong-young-jin sang-dae [First Shareholder Derivative Suit in Korea . . . People's Solidarity for Participatory Democracy Against the Former Management of KFB], MAEIL BUS. NEWS, June 3, 1997.

${ }^{257}$ PSPD was able to gather 894,702 shares to barely meet the new lowered $0.5 \%$ holding requirement of 820,000 shares under the SEA that became effective April 1, 1997. See Hong-yul Kim, supra note 256.

258 See Judgment of July 24, 1998, Seoul Chi-bang-pop-won [District Court], Jae 17 Min-sa-hap-ui-bu [17th Civil Division], 98 Kahap 39907; Byung- 
The compensatory award of the shareholder derivative action and the cancellation of the shareholders' meeting had a powerful impact on the burgeoning shareholder movement. ${ }^{259}$ The cases served to impress upon Korean management the importance of their responsibilities and duties to their shareholders and the consequences they may face as a result of their decisions. ${ }^{260}$

\subsection{Monitoring Management Decisions: Samsung Electronics and SK Telecom}

Recent investor pressure against some of Korea's premier blue chip companies has sent a powerful message that all companies must pay heed to their shareholders. ${ }^{261}$ In March 1998, organized shareholders attended the Samsung Electronics Corporation's annual shareholders' meeting and questioned its management about a variety of business decisions at unprecedented levels. ${ }^{262}$ Instead

moon Gong, Jun-jik-eun-baeng-jang-deung 4 myung-ae 400 ubk won bae-sang pangyul [400 Billion Won Judgment Against Four Including Former Bank President], L. TMMES (Seoul), July 27, 1998, at 2; Slater, supra note 30 (stating that "the decision sent shock waves through boardrooms").

259 See Dae-yon Kim, supra note 256, at 111-12. Other notable examples of shareholder lawsuits that were raised thereafter include an action brought by minority shareholders against Korea Telecom and Samsung Electronics. See Insoon $\mathrm{Kim}$, supra note 69; infra Section 4.4. Minority shareholders also recently brought a 67 billion won (U.S. \$55 million) shareholder derivative action against the directors of the now defunct Daedong Bank. See Ui-ho Song, Twoechool-eun-haeng so-aek-joo-joo chut so-song [Minority Sharebolder's First Lawsuit Against Defunct Bank], JOONGANG ILBO, Oct. 30, 1998, at 31.

260 See Kang-eun Lee, So-aek-joo-joo-dae-pyo cbut seung-so/ui-mi-wa gwa-jang [First Sharebolder Derivative Suit Victory/Meaning and Impact], DONGA IIBO, July 24,1998 , at 3.

${ }^{261}$ See Hae-won Choi, supra note 209, at 13 (noting that "[i]nvestors are watching a new indicator in South Korea: minority-shareholder activism"); Seong C. Gweon, Yes, There Is Hope, KOREA HERALD, Mar. 31, 1998 ("[T] he best thing to happen is that shareholders, nothing but owners, pay attention to their own wealth and interests. What happened to both SK Telecom and Samsung Electronics must have sent a clear message to the 'owners' of companies in this country.").

${ }^{262}$ See Namju Cho, Halting Pace of Korea Inc. Reforms Is Highlighted: Samsung Electronics Meeting Indicates Sharebolders Have Far to Go in Asserting Themselves, ASIAN WALL ST. J., Mar. 30, 1998, at 4. The management of Samsung Electronics was specifically questioned on its relation to Samsung's disastrous venture into the automobile industry and its near billion dollar failed investment in the U.S. personal computer manufacturer AST. Shareholders also challenged the propriety of Samsung Electronics' private issuance of convertible bonds to the son of the chairman of the Samsung Group at a tremendous discount. See id. 
of a somnolent and scripted thirty-minute affair, the meeting lasted for a record sixteen hours. ${ }^{263}$

Shareholders proceeded to exercise their various newfound rights under the KCC. Shareholders first requested an inspection of the contents of the board of directors' minutes. ${ }^{264}$ The management of Samsung Electronics initially did not comply with this request, but changed its position when the Suwon District Court issued a three million won fine against it. ${ }^{265}$ Shareholders then commenced a shareholder derivative action against various directors of Samsung Electronics on several counts. The action included claims concerning bribes paid to two former presidents and illegal trading with its subsidiaries. ${ }^{266}$ These various events forced many to realize that even Korea's premier companies must not disregard the interests of their shareholders and helped reorient companies to understanding that management must in fact respect the interests of their shareholders. ${ }^{267}$

In contrast, at about the same time in March 1998, the management of SK Telecom ("SKT") accepted a host of shareholder demands before its annual shareholders' meeting. ${ }^{268}$ Such an acceptance was a milestone in Korean corporate history. This agreement followed the first proxy solicitation initiated by a for-

${ }^{263}$ See id. In the 1999 annual shareholders' meeting, shareholders raised additional issues. Attempts to negotiate a compromise failed, and Samsung Electronics was able to obtain the necessary votes to amend its articles of incorporation to exclude cumulative voting. See Young-i Lee, So-aek-ju-ju 4-daegroup ju-chong kyuk-dol [Minority Sharebolders of 4 Major Groups Clash at Shareholder Meetings], DONGA ILBO, Mar. 21, 1999.

264 See KCC art. 396.

${ }^{265}$ See Hyo-jae Lee, I-sa-bwoi-gi-rok yeol-lam-gub-bu, chae-bol-ae gwa-tae-ryo bu-gwa [Rejection of Inspection of Board of Directors Minutes Leads to Fine Against Chaebol], CHOSUN ILBO, June 13, 1998.

266 See Myung-jin Lee, [Cham-yuh-yon-dae] Sam-sung-jun-ja gyung-young-jinsang-dae son-bae-bae-sang [PSPD Files a Compensatory Action Against SEC's Management], CHOSUN ILBO, Oct. 20, 1998.

267 See Don Kirk, Shareholders Take on Big Seoul Firms, INT'L HERALD TRIB., Mar. 22, 1999, at 11 ('Shareholders' meetings, traditionally pro forma affairs in which the executives of large companies faced no criticism, much less opposition, took a different turn this year because of South Korea's economic crisis.").

268 See Seong C. Gweon, supra note 241; Byung-soo Kim, So-aek-joo-joowoon-dong cham-yub-yun-dae-SK hap-ui-ui ui-mi [Minority Sharebolder Movement: Meaning of the PSPD-SK Agreement], HANGYORAE SHINMUN (Seoul), Mar. 26, 1998; Jong-won Koh \& Soon-hyun Hwang, Chae-bol-do 'too-myung gyung-young' yak-sok ba-da-nae [Obtaining a 'Transparent Management' Promise from a Chaebol], CHOSUN ILBO, Mar. 27, 1998, at 9. 
eign shareholder. ${ }^{269}$ SKT's management not only agreed to elect two outside directors and an independent auditor, but also agreed to accept the candidates chosen by shareholders to act in these positions. ${ }^{270}$

Next, several important amendments were made to the articles of incorporation. The new articles of incorporation provide that interconglomerate trading within the SK Group between related or sister companies that are in excess of ten billion won (U.S. $\$ 8.33$ million) must be approved by a majority of the outside directors. As a result, outside directors were recently able to reclaim 300 billion won (U.S. $\$ 216$ million) that was subsidized in the form of commercial paper to several sister companies. ${ }^{271}$ SKT also agreed to recover 300,000 shares that were improperly given to a sister company. ${ }^{272}$ Overall, in 1998, outside directors amended six out of twelve interconglomerate deals that they reviewed and rejected two deals altogether. ${ }^{273}$ These efforts by outside directors and auditors in particular were among the most successful examples of internal supervision under the new corporate environment. ${ }^{274}$

Despite this progress in 1998, management consistently rejected various proposals by shareholders in 1999 . First, they amended the company's articles of incorporation to exclude cu-

${ }^{269}$ See Gwang-am Chun, 'Tiger' deung 4 gae woe-gook-gae fund SK Telecom 'Joo-joo-gwon' noon-dok [Four Foreign Funds Including Tiger Eye 'Sharebolder Rights' in SK Telecom], DONGA ILBO, Mar. 17, 1998, at 21.

270 See Jon E. Hilsenrath, Directors Get Tough with SK Telecom, ASIAN WALl ST. J, Sept. 29, 1998, at 1 [hereinafter Hilsenrath, Directors Get Tough]; Jon E. Hilsenrath, In Seoul: Tiger Won Telecom Fight, but Locals May Win War, ASIAN WALL ST. J., Mar. 23, 1998, at 19 [hereinafter Hilsenrath, Tiger Won]. Another significant point was that foreign investors for one of the first recorded times joined minority investors in officially making various demands towards management. See Hong-gi Kim \& Soon-hyung Hwang, Woe-gook-fund "joo-chong pyo-dae-gyul" sun-un [Foreign Funds Declare a "Sharebolders' Meeting Vote Challenge'], CHOSUN ILBO, Mar. 17, 1998, at 12.

271 See Hilsenrath, Directors Get Tough, supra note 270, at 1; Soon-hyun Hwang, Sa-woe i-sa wui-ryuk 'gwa-shi' [Outside Directors 'Demonstrate' Their Power], CHOSUN ILBO, Oct. 1, 1998, at 27.

272 See Hwang, supra note 271, at 27.

273 See Sa-woe i-sa: sung-gong sa-rae-SK Telecom [Outside Directors: A Successful Case-SK Telecom], MAEIL BUS. NEWS, Mar. 16, 1999.

274 See id. (citing how, unlike other corporations, the outside directors held over 80 discussion meetings and how outside directors were selected by minority shareholders). 
mulative voting. ${ }^{275}$ Furthermore, SKT's outside auditor became the first auditor to call a shareholders' meeting under the newly established Article 412-3. The auditor convened the meeting because of his objections to a controversial new stock issue. ${ }^{276}$

Nevertheless, SKT's management was praised for its initial willingness to accept a considerable degree of the proposals by its shareholders at the time. ${ }^{277}$ Some skeptics, of course, claim that these changes were only possible because management could not afford to ignore foreign investors, who held more than a thirtythree percent stake at the time. ${ }^{278}$ Yet, SKT announced it would be willing to establish an audit committee for the company, one of the first in Korea. ${ }^{279}$ Overall, the managerial changes accomplished in the SKT case offer a glimpse into the future of corporate governance in Korea. ${ }^{280}$

275 This became possible because, in contrast to the government's overall efforts to strengthen accountability and transparency through the adoption of cumulative voting, the critical $18 \%$ stake of SKT held by Korea Telecom, a public enterprise, voted with management to exclude cumulative voting. See Sung-gun Cho, Jip-jung-too-pyo-jae-ui byang-bang [The Future Direction of the Cumulative Voting System], KOREA ECON. DAILY, Mar. 22, 1999.

276 See Ji-hun Lee, Chae-bol-chong-soo bae-im-an joo-chong-su chut-pyo-gyul [First Vote at Sharebolders' Meeting on Termination of a Chaebol Chairman], CHOSUN ILBO, Aug. 28, 1999.

277 See Hilsenrath \& Cho, supra note 204, at 1 (noting that it is "likely to be regarded as a landmark"). For comments on the limitations of the SKT case and some of the negative aspects of its management, see Jon E. Hilsenrath, Rethinking Asia: The Search for Solutions, ASIAN WALL ST. J., Oct. 26, 1998, at S4; Craig Karmin \& Jane L. Lee, Fund Managers Object to Plan for Korean Issue, ASIAN WALL ST. J., June 17, 1999, at 1.

${ }^{278}$ The limitation on foreign ownership of SKT which exists under a special law was raised to $49 \%$ as of July 1,1999 . See Electronic Communication Business Law, Law No. 4394 of 1991 (amended Law No. 5385 of 1997), arts. 6, 7.

279 See Soon-Hyun Hwang, SK Telecom gom-sa-byub-ui-bwoe-ui-bwoe chulbum [SK Telecom Establishes Audit Committee], CHOSUN ILBO, May 13, 1999.

280 One of the most significant signs of progress recently occurred when Dacom, Korea's leading internet service provider and part of the LG conglomerate, accepted proposals of PSPD. Among other things, Dacom agreed both to elect half of its eight directors as outside directors, and to establish an audit committee with two-thirds of its members as outside directors. Both of these measures occurred one year ahead of the SEA's requirements. PSPD has been given the right to nominate two of the outside directors. Dacom has also agreed to require that the audit committee approve interconglomerate trading and special issues of stocks and bonds. See Business in South Korea: Career Path, ECONOMIST, Apr. 1, 2000, at 59-60; Ji-hoon Lee \& Hee-chun Cho,So-aek-ju-juun-dong chut gyul-sbil. . . Dacom tu-myung-bwa-bab-ui [First Fruits for Minority 


\section{CONCLUSION: REORIENTATION OF CORPORATE KOREA AND ISSUES FOR THE FUTURE}

The recent revisions to the Commercial Code mark a significant transition in Korea's corporate regulatory environment. All of these reforms should be consolidated by the following factors. First, foreign investors will increasingly play a larger role in Korean corporations and the utilization of the $\mathrm{KCC}^{281}$ The ownership restrictions for foreign investors have been completely lifted in almost all listed companies. ${ }^{282}$ As of May 25, 1998, foreign investors are no longer restricted from hostile takeovers. ${ }^{283}$ Foreign investors, in fact, already own twenty percent of the total volume of listed stock on the Korea Stock Exchange, including majority shares in several blue chip companies. ${ }^{284}$

Representatives of foreign investors sit on the board of directors of such institutions as Korea Exchange Bank and SKT. ${ }^{285}$ While they still might be hesitant at present, companies realize that foreign investors will not be as passive as Korean shareholders. Companies with large foreign ownership must particularly pay attention. ${ }^{286}$ For instance, Samsung Electronics and SKT, which both have substantial foreign ownership, have been paying

Sharebolder Movement . . . Dacom Agrees to Become Transparent], CHOSUN ILBO, Mar. 7, 2000.

281 See Hong-ryul Chun, supra note 110, at 76-77; Charles Lee, Business Investment: Open Sesame: South Korea Warms Toward Foreign Investors, FAR E. ECON. REV., Dec. 24, 1998, at 51 (citing recent examples of foreign investment such as Volvo's U.S. $\$ 720$ million purchase of Samsung's constructionequipment division, BASF's U.S. $\$ 600$ million purchase of Daesang's animalfeed-additive business and British Telecom's U.S. $\$ 373$ million equity stake in LG Telecom).

282 The foreign ownership restriction was lifted on May 25, 1998, excluding certain public companies. See Foreign Securities Trading Regulation, Financial Supervisory Service.

${ }^{283}$ See Foreigner Investment and Foreign Capital Inducement Act, Law No. 5538 of 1998 (amended by Foreigner Investment Promotion Act, Law No. Sept. 16, 1998).

${ }^{284}$ See [Joo-joo-chong-bwoe] Hot Issue ... 5 dae group 5 gae gi-up si-kkeu-rop-da [Hot Issues at Shareholders' Meetings... . Noisy at the Five Largest Companies of the Five Largest Groups], MAEIL BUS. NEwS, Mar. 3, 1999.

${ }_{285}$ See Sara Webb, Asian Companies Open Themselves Up to Foreigners, ASIAN WALL ST. J., July 28, 1998, at 22.

286 See generally Jane L. Lee \& Hae Won Choi, Korean Firms Resist Change at Key Meetings, ASIAN WALL ST. J., Mar. 22, 1999, at 1 (noting that foreign shareholders were more active in the current year's shareholders' meetings). 
heightened attention to the demands of foreign shareholders. ${ }^{287}$ Overall, a significant but subtle disciplining effect on Korean corporate governance is emerging. ${ }^{288}$

In addition to foreign investors, Korean institutional investors, which now own almost thirty-five percent of the total listed shares, are also on the brink of becoming more active actors. ${ }^{289}$ Until last year, institutional investors have been restricted in exercising their voting rights from customer accounts. ${ }^{290}$ At most, they occasionally objected to mergers or merely claimed appraisal rights. ${ }^{291}$ As witnessed in the annual shareholders' meetings that were held in the spring of 1999 , overall they still remained passive. ${ }^{292}$ Most institutional investors, for instance, generally abstained or voted against the adoption of cumulative voting. ${ }^{293}$ Yet, with the explosion of closed-end funds and unit trust investment in 1999, and the consequent increase in competition among institutional investors, this predisposition is likely to change.

${ }^{287}$ See Bong-kwon Park, Samsung Electronics, SK Telecom, Korea Telecom deung jip-jung-too-pyo-jae bae-jae-ae woe-gook-in byup-jo [Samsung Electronics, SK Telecom, Korea Telecom Seek Cooperation of Foreigners in Excluding Cumulative Voting], MAEIL BUS. NEWS, Mar. 12, 1999.

${ }^{288}$ See Hae-won Choi, supra note 209, at 13 (noting that "foreign investors praise the changes pushed through by minority shareholders"); Sung-il Hong, Woe-gook-in-ji-boon man-eun sang-jang-sa-deul joo-chong bi-sang [Listed Companies with Large Foreign Ownership on Alert for Their Sharebolders' Meetings], JOONGANG ILBO, Jan. 10, 1998, at 25; Moon Ihlwan, supra note 204, at 52;.

289 See KSE, Joo-shik [Stock], Apr. 1999; Jae-won Lee, supra note 27, at 164; Hong-ryul Chun, supra note 110 , at 77.

290 See Jae-won Lee, supra note 27, at 167-77.

291 See Gi-gwan gi-up-gyung-yong gam-sbi na-sut-da [Institutional Investors Begin Monitoring Corporate Management], MAEIL BUS. NEWS, Feb. 27, 1997; Yoon-jae Han, Gi-gwan-too-ja-ga ui-gyul-gwon juk-geuk baeng-sa-reul [Institutional Investors Should Actively Exercise Voting Rights], CHOSUN ILBO, June 30, 1999 , at 6 (providing a list of some of the rare instances where institutional investors have raised their objections).

292 See Hun-soo Kim \& Yong-hae Choi,Jip-jung-too-pyo-jae non-lan... sangjang-sa bae-jae-chu-jin-ae gi-gwan-too-ja-ga jub-ji na-sub [Dispute Concerning Cumulative Voting... Institutional Investors Seek to Block Attempts by Listed Companies to Exclude Provision], MAEIL BUS. NEWS, Feb. 12, 1999. But cf. Jae-oh Yoon, 12 wol gyul-san sang-jang-sa joo-chong i-bun-joo-boo-tub bon-gyuk gae-mak [Listed Companies with Accounting Years Ending in December Commence Sharebolders' Meetings This Week], MAEIL BUS. NEWS, Feb. 21, 1999 (describing that Daehan Investment Trust and Korea Investment Trust did object to a recent merger between Hyundai Motors and Hyundai Motor Service).

293 See Hun-soo Kim \& Yong-hae Choi, supra note 292. 
Furthermore, Korea is facing considerable peer pressure from international organizations such as the Organisation for Economic Co-operation and Development ("OECD") to modify its corporate regulations to reflect newly emerging international standards. ${ }^{294}$ Korea accepted various aspects of the OECD proposals. Among the reforms adopted, outside directors must comprise one-quarter of the board of listed companies. ${ }^{295}$ Although outside directors face limitations in all corporate systems, overall they should be able to provide additional checks and balances to the management structure dominated by the principal shareholders. Moreover, large companies and securities firms with assets of over two trillion won face even stricter standards. ${ }^{296}$ First, they must elect at least three outside directors to their boards in 2000 and more than half by $2001 .{ }^{297}$ These outside directors also must be elected through nominating committees. Second, they must establish audit committees where more than two-thirds of their members are outside directors. ${ }^{298}$ In light of the significant position of financial companies, the standard holding requirements to exercise shareholders rights have been lowered by an additional fifty percent in the case of shareholders of securities companies. ${ }^{299}$

The 1995, 1998, and 1999 revisions to the KCC represent the third, fourth, and fifth amendments in a period of over thirty years. Although various changes still need to be made, unimaginable progress has been achieved at an alarming pace. The onset of the Korean financial crisis in late 1997 ironically served as a catalyst for further reforms. Korea attempted to tackle some of the central problems of its corporate regulation such as the lack of ac-

${ }^{294}$ See Yong-yool Kim, Woo-ri-na-ra-ui gi-up-ji-bae-goo-jo mo-bum-gyu-yak jae-jung ui-ui-wa bang-hyang [The Meaning and Future Direction of the Establishment of Best Practices for Korean Corporate Governance], 39 SANG-JANG-HYUP 9 (1999).

295 See SEA art. 191-16.

296 See id.; SEA arts. 54-5, 54-6.

297 See SEA art. 191-16, annex art. 8.

298 See SEA arts. 191-17, 54-6. See generally Bup-gae-jung jak-up so-gae [Introducing Preparations of Law Amendments], L. TIMES, Mar. 25, 1999, at 3; Bokki Hong, I-sa-bwoe-wa geu ui-won-bwoe: gam-sa-ui-won-bwoe-ui do-ip-yub-boo-ae dae-han gum-to [Board of Directors and Its Committees: Reviewing the Possibility of Adopting Audit Committees], 39 SANG-JANG-HYUP 51 (1999); Jong-ho Kwon, Il-bon-ui gi-up-ji-bae-goo-jo dong-byang-gwa woo-ri-na-ra gam-sa-jae-do-ui gae-sun [Recent Trends in Japanese Corporate Governance and Improving the Korean Audit System], 39 SANG-JANG-HYUP 72 (1999).

299 See SEA art. 64. 
countability in corporate governance, weak directors and auditors, ineffective shareholder rights, and transparency standards. External corporate governance has been promoted by facilitating mergers and acquisitions.

Various reforms still need to be pursued. Class actions suits are still not permitted. Although a proposed law to permit class actions has been drafted, it has continued to linger in the National Assembly. ${ }^{300}$ Despite the recent amendments, the current threshold shareownerhip requirements still act as a barrier to the exercise of shareholder rights and need to be lowered further.

Nevertheless, the recent amendments to Korea's Commercial Code should increase the competitiveness of corporate Korea. Instead of operating in a vacuum, Korean corporations can only become more efficient institutions by finally facing at least some degree of monitoring controls and internal and external corporate governance discipline. These changes can only serve to enhance the international competitiveness of corporate Korea.

${ }^{300}$ See The National Assembly of the Republic of Korea (visited Nov. 1, 1999) < http://www.assembly.go.kr > . The IMF initially requested the inclusion of class action suits. See Gyung-ho Yoon, So-soo-joo-joo jib-dan-so-song-jae [Minority Sharebolder Class Action], MAEIL BUS. NEWS, Dec. 24, 1997. 